Article

\title{
Geochemical and Dynamic Model of Repeated Hydrothermal Injections in Two Mesozoic Successions, Provençal Domain, Maritime Alps, SE-France
}

\author{
Namam Salih $1,2, * \mathbb{0}$, Howri Mansurbeg ${ }^{3,4}$ and Alain Préat ${ }^{5}$ \\ 1 Faculty of Science, Department of Petroleum Geosciences, Soran University, Soran, Erbil 44008, \\ The Kurdistan Region of Iraq, Iraq \\ 2 Scientific Research Center (SRC), Soran University, Soran, Erbil 44008, The Kurdistan Region of Iraq, Iraq \\ 3 General Directorate of Scientific Research Center, Salahaddin University-Erbil, Erbil 44002, \\ The Kurdistan Region of Iraq, Iraq; Howri.Mansurbeg@uwindsor.ca \\ 4 School of the Environment, University of Windsor, Windsor, ON N9B 3P4, Canada \\ 5 Res. Grp.-Biogeochemistry \& Modelling of the Earth System, Université Libre de Bruxelles, \\ 1050 Brussels, Belgium; apreat@ulb.ac.be \\ * Correspondence: namam.muhammed@gmail.com
}

Received: 9 August 2020; Accepted: 30 August 2020; Published: 31 August 2020

\begin{abstract}
A field, petrographic and geochemical study of two Triassic-Jurassic carbonate successions from the Maritime Alps, SE France, indicates that dolomitization is related to episodic fracturing and the flow of hydrothermal fluids. The mechanism governing hydrothermal fluids has been documented with the best possible spatio-temporal resolutions specifying the migration and trapping of hydrothermal fluids as a function of depth. This is rarely reported in the literature, as it requires a very wide range of disciplines from facies analysis (petrography) to very diverse and advanced chemical methods (elemental analysis, isotope geochemistry, microthermometry). In most cases, our different recognized diagenetic phases were mechanically separated on a centimetric scale and analyzed separately. The wide range of the $\delta^{18} \mathrm{O}_{\mathrm{VPDB}}$ and ${ }^{87} \mathrm{Sr} /{ }^{86} \mathrm{Sr}$ values of diagenetic carbonates reflect three main diagenetic realms, including: (1) the formation of replacive dolomites (Type I) in the eogenetic realm, (2) formation of coarse to very coarse crystalline saddle dolomites (Types II and Type III) in the shallow to deep burial mesogenetic realm, respectively, and (3) telogenetic formation of a late calcite cement (C1) in the telogenetic realm due to the uplift incursion of meteoric waters. The Triassic dolomites show a lower ${ }^{87} \mathrm{Sr} /{ }^{86} \mathrm{Sr}$ ratio $($ mean $=0.709125)$ compared to the Jurassic dolomites (mean $=0.710065)$. The Jurassic calcite $\left(\mathrm{C}_{\mathrm{J}}\right)$ shows lower $\mathrm{Sr}$ isotopic ratios than the Triassic $\mathrm{C}_{\mathrm{T}}$ calcite. These are probably linked to the pulses of the seafloor's hydrothermal activity and to an increase in the continental riverine input during Late Cretaceous and Early Cenozoic times. This study adds a new insight into the burial diagenetic conditions during multiple hydrothermal flow events.
\end{abstract}

Keywords: hydrothermal dolomite; diagenetic settings; optical petrography; geochemical; Triassic-Jurassic successions; Provençal Domain

\section{Introduction}

The formation of low- versus high-temperature dolomites in carbonate successions is attributed to separate diagenetic conditions and fluid origins [1,2]. Low temperature dolomitizing fluids are associated with near surface diagenetic fluids [3-5]. Hot dolomitizing fluids are either the result of 
high burial temperatures or the flux of hot hydrothermal (HT) fluids into colder, shallower buried carbonate succession environments [6-9]. The HT fluids are commonly formed by the upward flow of basinal brines [10], or deeply percolating meteoric waters [11] that interact with crystalline basement rocks [12]. In this paper, the petrographical characteristics and geochemical and isotopic compositions of dolomite and calcite in the Triassic-Jurassic successions are used to constrain the diagenetic conditions encountered within the framework of a constructed paragenetic sequence of dolomites in the Provençal Domain in SE France.

\section{Regional Geology}

The study area is located in the Provençal Domain close to the northeastern part of the Maritime Alps, in the southeast of France, bordered by NW Italy (Figure 1). The area, which is considered as the interior-most part of the European Proximal Margin [13], is underlain by the Argentera Massif from the southern part of the Dauphinois Domain. The Provençal Domain consists of Mesozoic rocks in shallow marine environmental settings [14] and Upper Carboniferous-Permian continental sediments overlain by Triassic rocks consisting of siliciclastics (Lower Triassic), tidal carbonates (Middle Triassic) and evaporites (Upper Triassic) [15].

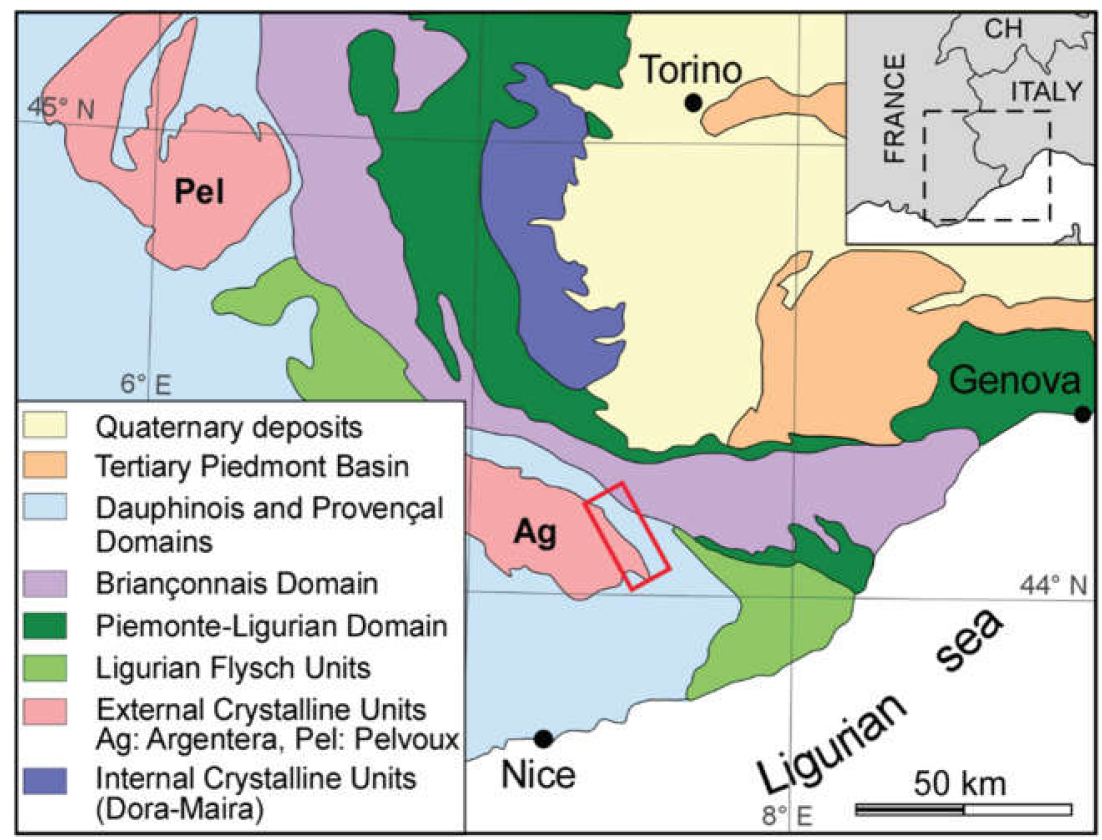

Figure 1. General geological map of the south-west Alps. The red rectangle shows a part of the study area (Provençal Domain) (after [14]).

The European paleo-margin experienced extensional and transtensional tectonics during the opening of the Alpine Tethys during the Jurassic and Cretaceous [16]. A subsequent regional unconformity followed the Triassic succession and encompasses the Late Triassic-Early Jurassic succession [14]. The emersion of the Provençal Domain during Early Jurassic times led to the formation of a carbonate platform followed by a continuous decrease in the sea level and the consequent establishment of a peritidal environment during the Berriasian $[17,18]$. The deposition of shallow-water marine carbonates continued during the Cretaceous [14]. The Mesozoic succession is separated from the Cenozoic deposits by a regional unconformity that is equivalent to the late Cretaceous-Middle Eocene interval [14]. A rapid lateral facies variation is observed in both Provençal and Dauphinois Domains and the Mesozoic succession is thinner toward the Provençal area [14]. 


\section{Methods and Materials}

Conventional and cathodoluminescence (CL) petrography was carried on 50 thin sections (out of total 98 samples) stained with Alizarin Red. The CL examinations were carried out on representative polished thin sections using CL model 8200 at operating conditions of 9-12 kV and a 300-400 $\mu \mathrm{A}$ gun current.

A total of $1.5 \mathrm{mg}$ of the 43 dolomite and calcite samples were dissolved in $3 \mathrm{M} \mathrm{HNO}_{3}$ for the purpose of elemental analysis. The solution was diluted with $2 \mathrm{~mL}$ of deionized $\mathrm{H}_{2} \mathrm{O}\left(\mathrm{N} 18.2 \mathrm{M} \Omega \mathrm{cm}^{-1}\right)$. The element concentrations are reported in ppm. The analytical errors are given as $\pm \%$ RSD. The $1 \sigma$-reproducibility for the major and trace elements of the two standard materials are $\pm 0.18 \mathrm{wt}$. $\%$ for $\mathrm{Ca}, \pm 0.081 \mathrm{wt}$. \% for $\mathrm{Mg}, \pm 22 \mathrm{ppm}$ for $\mathrm{Sr}, \pm 17 \mathrm{ppm}$ for Fe, $\pm 1 \mathrm{ppm}$ for Mn (CRM-512, $n=111)$, \pm 0.36 wt. \% for $\mathrm{Ca}, \pm 0.002$ wt. $\%$ for $\mathrm{Mg}, \pm 1 \mathrm{ppm}$ for $\mathrm{Sr}, \pm 12 \mathrm{ppm}$ for Fe and $\pm 1 \mathrm{ppm}$ for Mn (CRM-513, $n=111)$.

The oxygen and carbon stable isotopic analyses were performed by the reaction of powdered, micro-sampled calcite and dolomite with $100 \%$ phosphoric acid at $70{ }^{\circ} \mathrm{C}$ using a Gasbench II connected to a ThermoFisher Delta V Plus mass spectrometer. All values are reported in per mil relative to V-PDB. The reproducibility and accuracy were monitored by a replicate analysis of laboratory standards calibrated to international standards NBS19, NBS18 and LSVEC. Isotopic values are referred to the University of Erlangen PDB standard with reproducibilities of $\pm 0.2 \%$ or better.

The ${ }^{87} \mathrm{Sr} /{ }^{86} \mathrm{Sr}$ analyses were performed at the Institute for Geology, Mineralogy and Geophysics, Ruhr-Universität Bochum (Germany). According to the ICP-OES, the Sr concentration measurements need a carbonate sample with 250 to $350 \mathrm{ng}$ of Sr digested with $6 \mathrm{M}$ supra-pure $\mathrm{HCl}$ for about $24 \mathrm{~h}$ at room temperature in PFA beakers and evaporated until dry. Subsequently, the dried samples were re-dissolved in $0.4 \mathrm{~mL} \mathrm{HNO}_{3} 3 \mathrm{M}$. The $\mathrm{Sr}$ fraction was recovered using an ion exchange resin (Sr-resin TRISEM) with $0.05 \mathrm{M}$ and $3 \mathrm{M} \mathrm{HNO}_{3}$ applying $2 \mathrm{~mL}$ of distilled water. After evaporation, the dried sample material was treated with $1 \mathrm{~mL}$ of a $1: 1$ mixture of concentrated $\mathrm{HNO}_{3}: \mathrm{H}_{2} \mathrm{O}_{2}$ removing organic remains and subsequently dried again. Later, the samples were converted to chloride-form by applying $0.4 \mathrm{~mL} 6 \mathrm{M} \mathrm{HCl}$. The mean of 279 analyses of NIST standard NBS 987 was 0.710242 with a mean standard error of $0.000002( \pm 2 \mathrm{se})$ and mean standard deviation of $0.000032( \pm 2 \mathrm{sd})$, whereas the mean of 253 analyses of the USGS EN-1 standard was 0.709162 with a mean standard error of 0.000002 ( $\pm 2 \mathrm{se})$ and mean standard deviation of 0.000026 ( $\pm 2 \mathrm{sd})$.

\section{Results}

\subsection{Field Observation}

The studied carbonates display a complex fracture system with carbonate cemented breccias and zebra fabrics (Figure 2A,B and Figure 3). The brecciated fragments show angular edges cemented by coarse-crystalline dolomite. Brecciation is most extensive in the lower part of the Triassic section (Figure 2B). The development of stratabound zebra fabric in the Triassic series is associated with fracture networks with predominantly conjugated orientations extending for decimeters (Figure 2A). Dolomitization is the most common diagenetic alteration in the host carbonates in the Maritime Alps [18].

\subsection{Petrography of the Triassic-Jurassic Succession}

Petrographic characteristics are used to document the diagenetic fluids that influenced the Mesozoic carbonate successions in the Maritime Alps (Provençal Domain-SE France), their relative timing and burial history. The diagenesis of the carbonate is complex and includes several dolomite generations. 

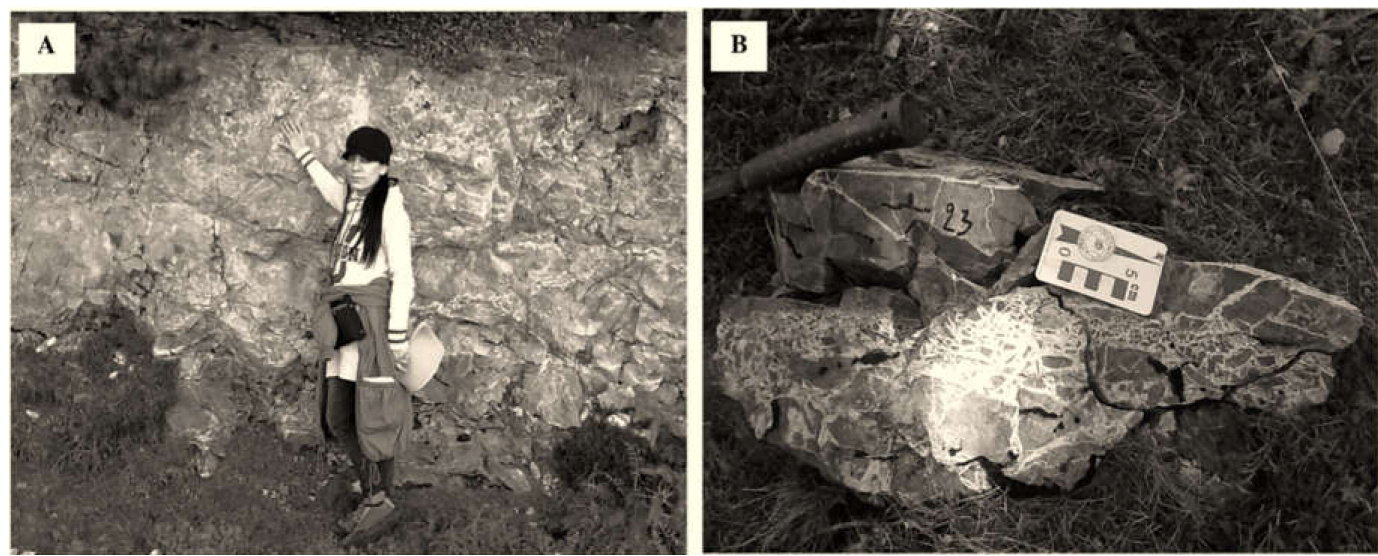

Figure 2. Triassic outcrops characterized by fractures arranged in horizontal and sub-vertical bands to the bedding planes, resulting in zebra-like structures (A), open fractures zones, and breccias (B).
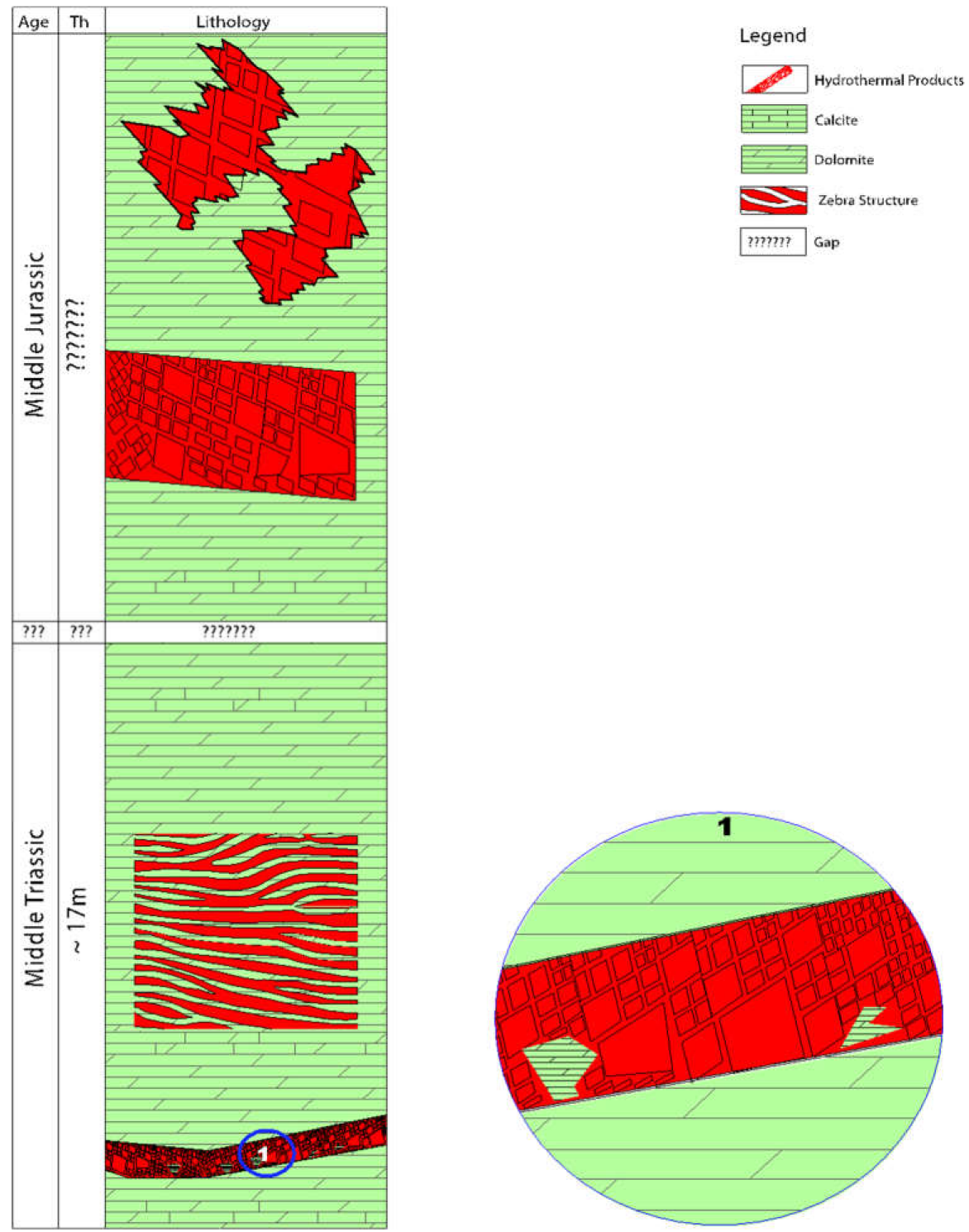

$\triangle$ Zebra Structure

$m m ?$ Gap

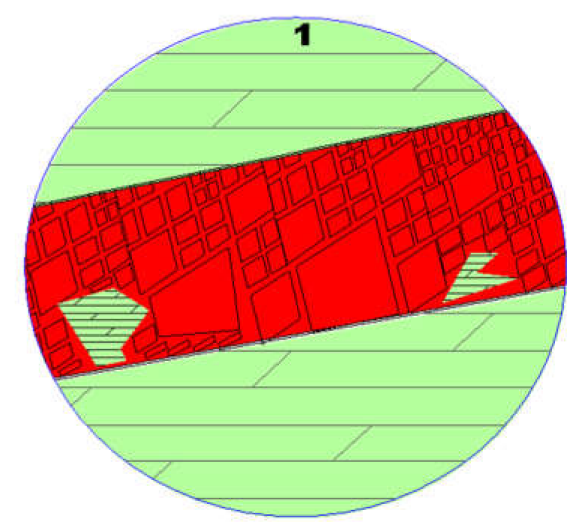

Figure 3. Basic stratigraphic litho-log of the Triassic and Jurassic carbonate rocks in Provençal Domain. The lower most part of Triassic rock (1) is extensively brecciated and the floated fragments have been cemented by saddle dolomite (see the enlarged part of this breccia on the right part " 1 "). The breccia is followed by another structure, i.e., zebra dolomites. 


\subsubsection{Middle Triassic Section}

The micrite and replacive microdolomite $\left(\mathrm{D} 1_{\mathrm{T}}\right)$ composition is more common in breccia and zebra fabrics of the Triassic than in the Jurassic carbonates. Despite strong dolomitization, the depositional features are still preserved including laminated algal/microbial mats and slightly compacted micritized ooids with darker micritic envelopes in grain-supported fabrics (Figure 4A,B). Dolomite 2 (D2 $\mathrm{T}$ ) is composed of medium to coarse grained anhedral-subhedral crystals $(70-200 \mu \mathrm{m})$ in a nonplanar to planar-s fabric. $\mathrm{D} 2_{\mathrm{T}}$ replaced the $\mathrm{D} 1_{\mathrm{T}}$ dolomite and display relict ooids (Figure $\left.4 \mathrm{~A}, \mathrm{~B}\right)$.
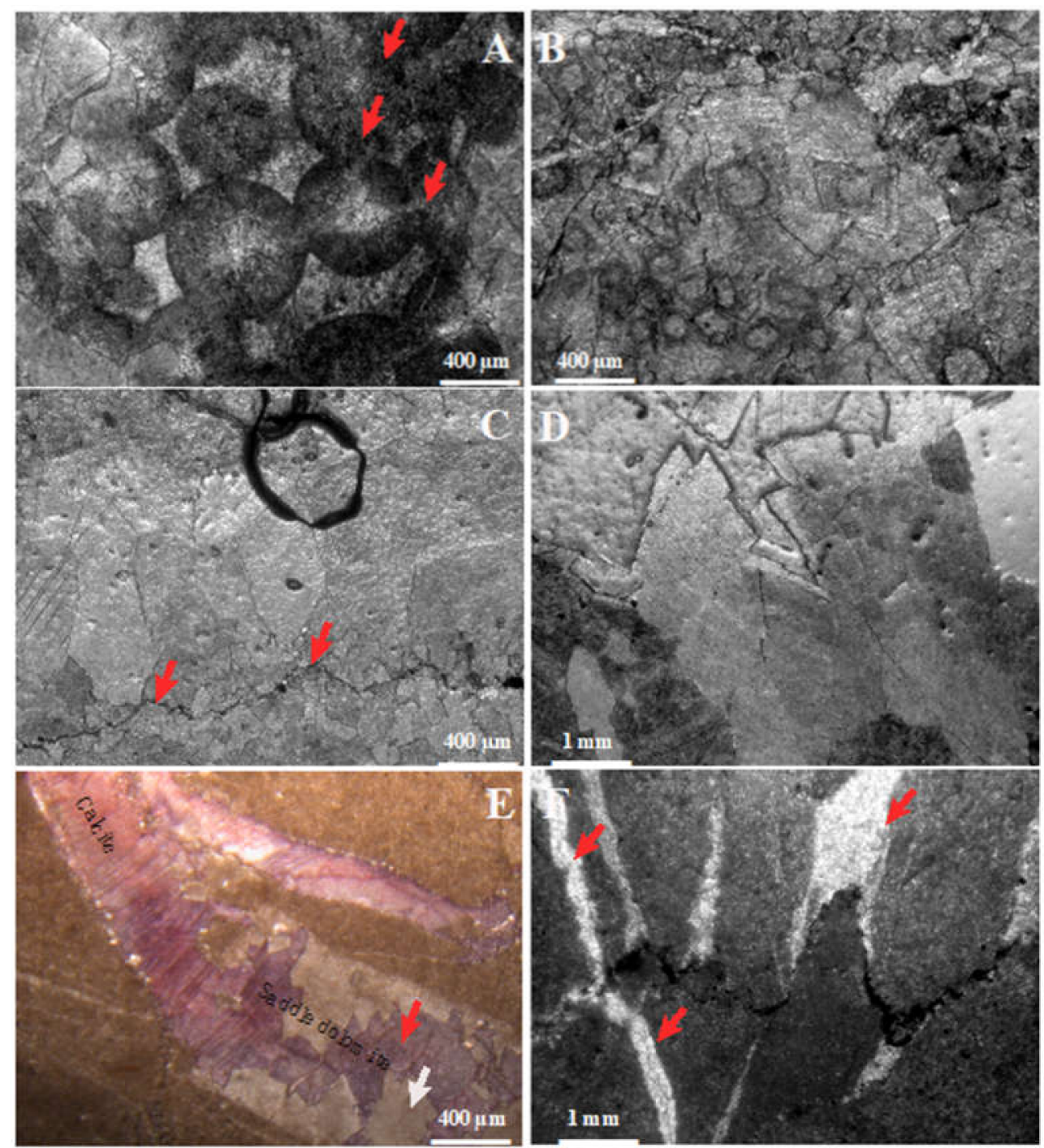

Figure 4. (A) The depositional texture is grain-supported with ooids (grainstones). The intergranular contacts between ooids are sutured and convexo-concave due to overburden load (arrows). (B) Transition from a mostly anhedral dolomite $\mathrm{D} 2_{\mathrm{T}}$ to a euhedral saddle dolomite $\mathrm{SD} 2_{\mathrm{T}}$ separated by an irregular stylolite indicating that these dolomites were formed at different time. (C) Early stylolite (arrows) cross-cuts SD1 1 with precipitation of sulfide minerals. (D) Light brown saddle dolomite $\mathrm{SD}_{\mathrm{T}}$, showing coarse crystal size and pressure dissolution. (E) Macroscopic fracture showing Fe-rich SD3 ${ }_{\mathrm{T}}$ (red arrow) and Fe-poor SD2 ${ }_{\mathrm{T}}$ (white arrow). A late-stage Fe-poor calcite cement appears at the top left (staining). (F) Arrows point to sets of tension gashes filled by Fe-rich $\mathrm{SD}_{\mathrm{T}}$ fracture. The fractures and columns of stylolite (red arrows) are in the same direction and this could be related to the mechanical overburden in the deep burial diagenetic setting. 
Saddle dolomite $\left(\mathrm{SD} 1_{\mathrm{T}}\right)$, which occurs as irregular compacted crystals $(0.3$ to $0.6 \mathrm{~mm})$ with nonplanar-s fabric, replaced $\mathrm{D} 2 \mathrm{~T}$. $\mathrm{SD} 1_{\mathrm{T}}$ commonly occurs in the dolostones and, less commonly, as vug-lining cement in fractures. Coarser saddle dolomite $\mathrm{SD} 2_{\mathrm{T}}$ crystals ( 0.5 up to $4 \mathrm{~mm}$ ) consist of homogeneous euhedral slightly curved, sometimes planar, crystals. In contrast to $\mathrm{SD} 2_{\mathrm{T}}, \mathrm{SD} 1_{\mathrm{T}}$ appears as a cement in irregular fenestrae and breccias and as zebra dolomite fabric. The brecciated dolostones $\mathrm{D} 2{ }_{\mathrm{T}}$ (clast sizes up to a few $\mathrm{cm}$ ) are cemented by various dolomitic types. $\mathrm{SD} 1_{\mathrm{T}}$ is distinguished from $\mathrm{SD} 2 \mathrm{~T}$ crystals by its fabric retentive, inclusion-free rims and inclusion-rich cores. $\mathrm{SD} 1_{\mathrm{T}}$ and $\mathrm{SD} 2_{\mathrm{T}}$ saddle dolomites are characterized by a similar growth zoning with bright red and dark red luminescence. The gray bands of $\mathrm{D} 2 \mathrm{~T}$ alternate with the white bands of the saddle dolomites (SD1, SD2), forming the zebra fabric and are thus genetically related to the fracturing of the dolostones. $\mathrm{SD}_{\mathrm{T}}$ and $\mathrm{SD} 2_{\mathrm{T}}$ are crosscut by low amplitude stylolites (Figure $3 \mathrm{C}$ ) that were aligned parallel to fracture-filling saddle dolomite.

Light brown colored, coarse-grained, euhedral, slightly planar, Fe-rich saddle dolomite crystals $\left(\mathrm{SD} 3_{\mathrm{T}}\right)$ are found in the breccias (Figure $\left.4 \mathrm{D}-\mathrm{F}\right)$. The breccias vary from clast-supported (jigsaw puzzle) to cement-supported textures (Figure $2 \mathrm{~B}$ ). $\mathrm{SD} 3_{\mathrm{T}}$ is associated with stylolites with sets of fractures or tension gashes. The tension gashes are parallel to the columns of stylolites and terminated at the wider end of the stylolite seam. SD3 $3_{\mathrm{T}}$ exhibited the typical saddle characteristics with a wavy extinction and curved crystal faces under a cross-polarized light, and has a uniform bright red luminescence under CL.

Euhedral, Fe-poor SD4 ${ }_{\mathrm{T}}$ saddle dolomite (Figure 5A) displayed alternating inclusion-rich cores and -free rims. The margins of $\mathrm{SD}_{\mathrm{T}}$ crystals were corroded and replaced by calcite $\left(\mathrm{C} 1_{\mathrm{T}} ;\right.$ Figure $\left.5 \mathrm{~B}, \mathrm{C}\right)$. Similar calcite filled the vugs and fractures and replaced $\mathrm{D} 2_{\mathrm{T}}, \mathrm{SD} 3_{\mathrm{T}}$ and $\mathrm{SD}_{\mathrm{T}}$ too.
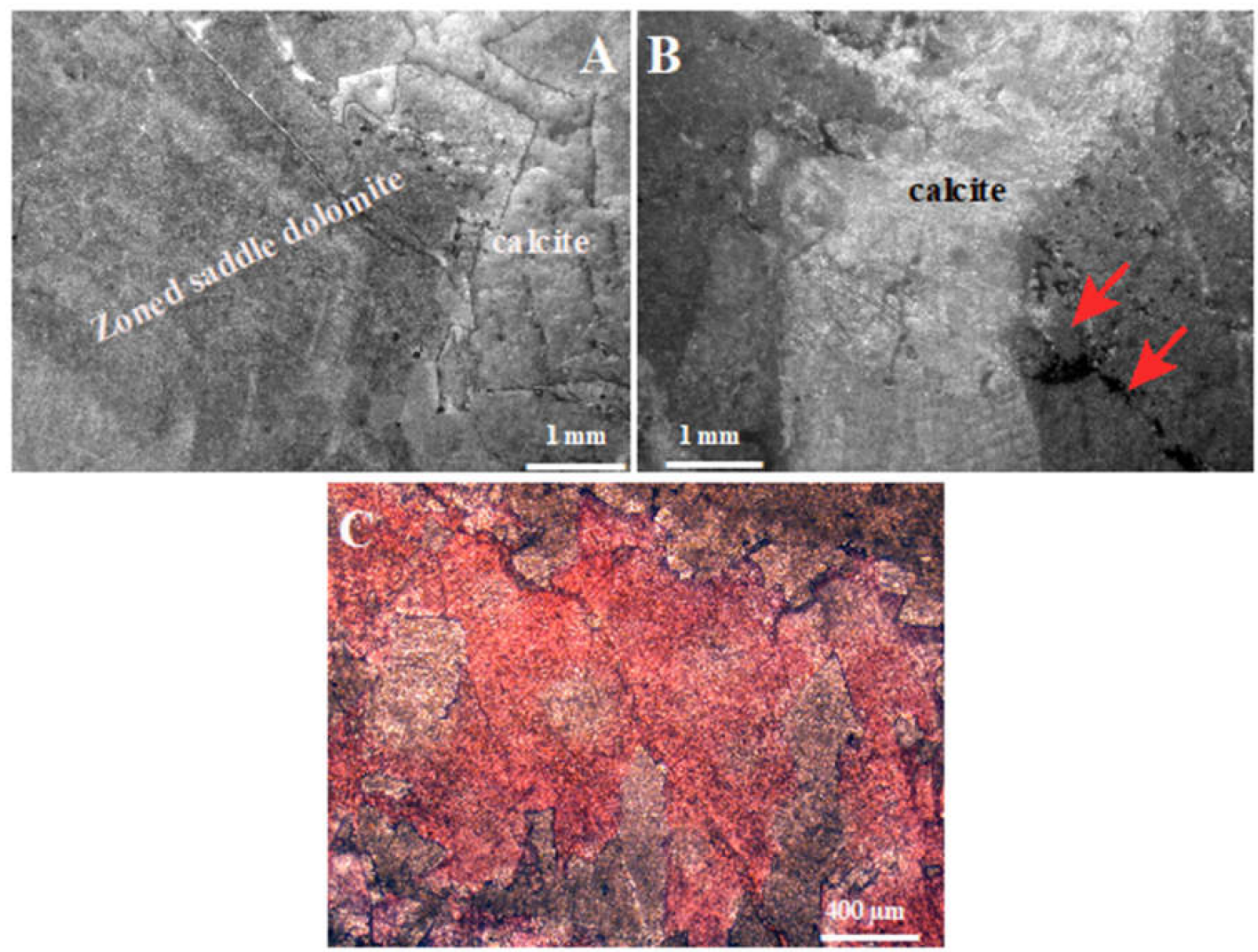

Figure 5. (A) The former saddle dolomite $\mathrm{SD}_{\mathrm{T}}$ leaving traces along the core and cortex of zoned $\mathrm{SD} 4_{\mathrm{T}}$, reveals that $\mathrm{SD} 4_{\mathrm{T}}$ was formed under different diagenetic conditions. $\mathrm{C} 1_{\mathrm{T}}$ filled the remaining secondary pores, and postdating the latter saddle dolomite. (B,C) Millimeter-sized fracture-filling Fe-poor, late stage calcite cement $\left(\mathrm{C}_{\mathrm{T}}\right)$, postdating late stylolite (arrows). 


\subsubsection{Middle-Upper Jurassic}

The peritidal Middle-Upper Jurassic carbonates in the Provençal region include ooidal packstones and grainstones, which are replaced by microcrystalline dolomite (10-300 $\mu \mathrm{m})\left(\mathrm{D} 1_{\mathrm{J}}\right)$ (Figure 6A). SD1 $\mathrm{J}$ replaced $\mathrm{D}_{\mathrm{J}}$ (Figure 6B). A fabric destructive, second saddle dolomite generation (SD2 J) with subhedral-euhedral, nonplanar crystals $(>1 \mathrm{~mm})$ fill fractures and vugs (Figure 6C).
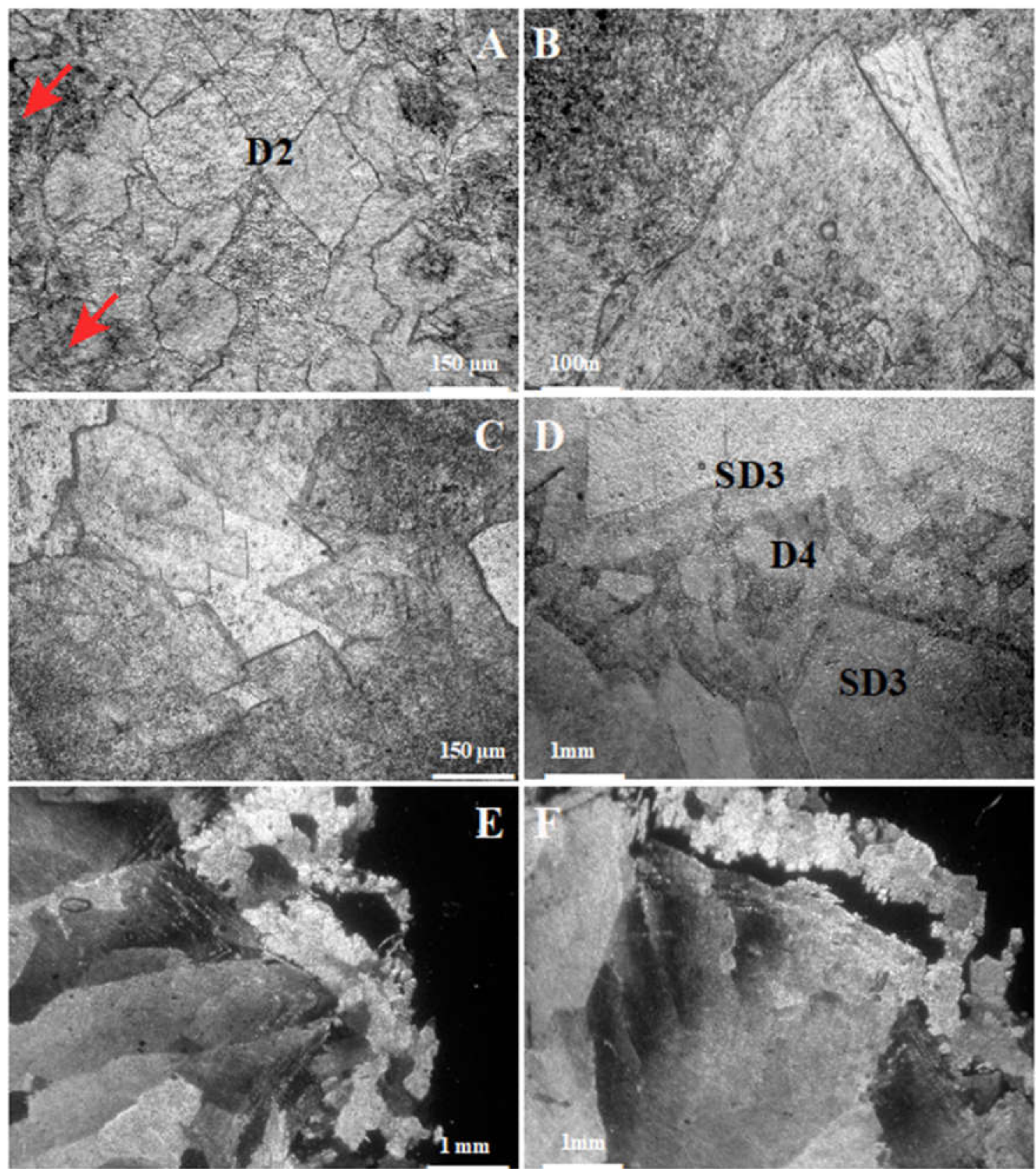

Figure 6. (A) Mostly planar-s dolomite D2 ${ }_{\mathrm{J}}$ with remaining of a former replacement dolomite $\mathrm{D}_{\mathrm{J}}$ "lithorelic" (arrows) showing dissolution and irregular compacted grain boundaries. Micrite of precursor facies on the top left corner. (B) Saddle dolomite-type SD1 $\mathrm{J}$ matrix. The core is rich in inclusions. Thus, this dolomite facies is a key for the replacement of a former dolomite. (C) Secondary porosity filled by saddle dolomite SD2 $\mathrm{J}$ cement. (D) Secondary porosity occluded by late dolomite D4 of different grain sizes, within SD3 . (E,F) Saddle dolomite SD5 is characterized by strongly curved crystal boundaries and a sweeping extinction under crossed nicols. D, Dolomite; SD, Saddle dolomite. 
Yet another phase of coarse-crystalline (several $\mathrm{mm}$ across), euhedral, nonplanar to planar, beige colored saddle dolomite $\left(\mathrm{SD} 3_{\mathrm{J}}\right.$ ) (Figure 6D), which fills the fractures or replaces the dolomitic matrix, was recognized. SD3 $\mathrm{J}$ is postdated by a dark-grey dolomite with different sizes and shapes (D4) of filling space between SD3 3 crystals (Figure 6D).

Another coarse-crystalline, euhedral, nonplanar, multizoned, red luminescent fracture and vug-filling saddle dolomite (SD5J) (Figure 6E,F) was observed. SD5J crystals are characterized by alternating inclusion-rich and inclusion-free zones. High-amplitude stylolites cross cut the fracture-filling saddle dolomites; no tension gashes were observed. The SD6 $\mathrm{J}$ dolomite is distinguished from the previous saddle dolomites by its elongated crystal shapes (Figure 7A-C). This SD6J dolomite is densely packed and systematically associated with D4 (Figure 6D). CL revealed an alteration of thick red luminescence (SD5J) and thick nonluminescent SD6 (Figure 8B,C). In addition, thin bright red luminescence is associated with fractures that postdated SD6 $\mathrm{J}$.
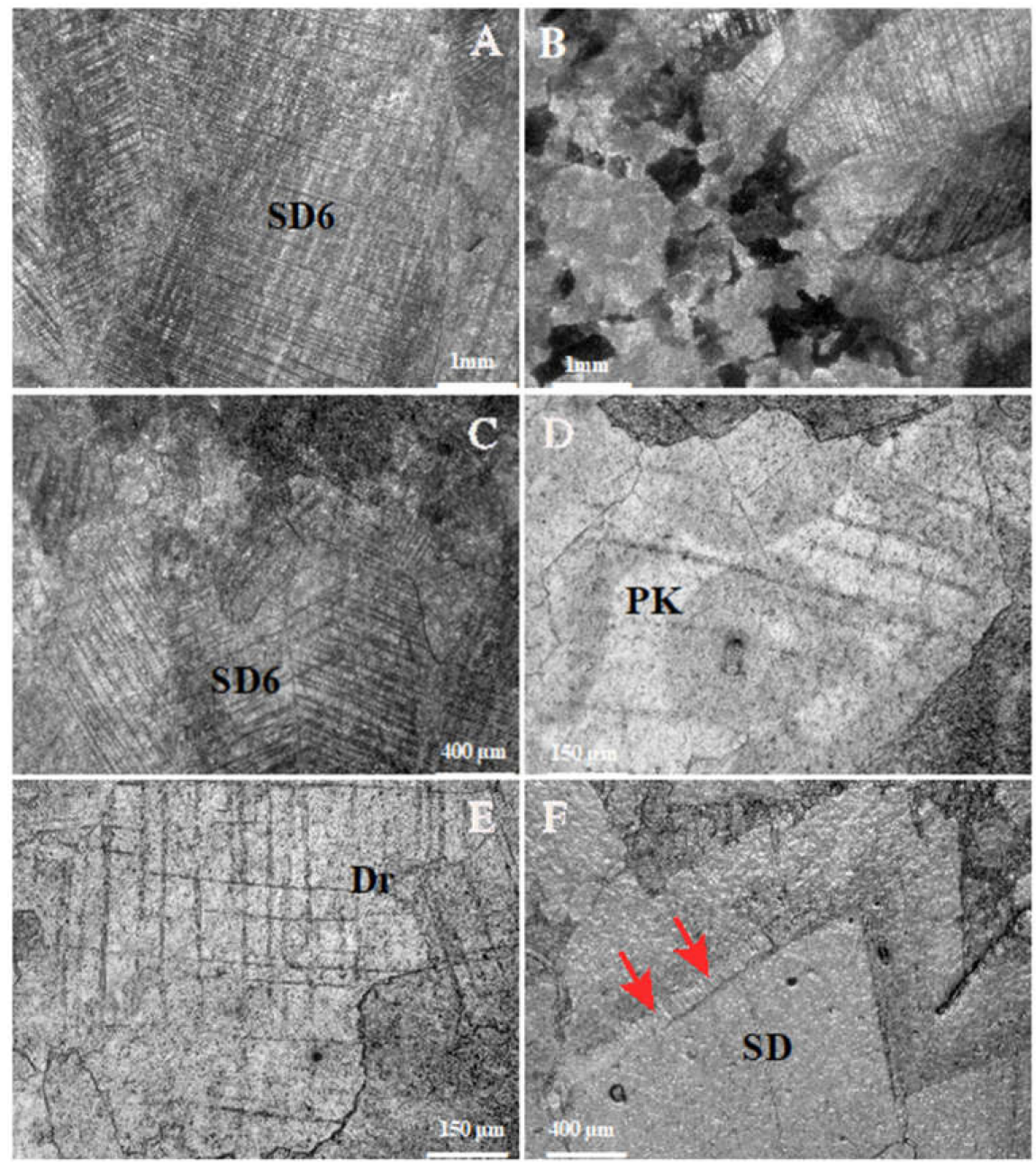

Figure 7. (A-C) More than 1mm sized-dolomite crystals SD6 $\mathrm{J}$ with two sets of cleavages, precipitated in fractures in contact with recrystallized dolomite. SD6, shows etching and overgrowth of coarse dolomite. (D,E) Saddle dolomite rhomb with an irregular, selectively dissolved outline which predates the poikilotopic texture within the recrystallized dolomite matrix. Two sets of curvature twin laminae, and dissolution of high amplitude stylolite intersecting coarse recrystallized dolomite crystals (the upper side part of Dr and lower side part of E). (F) Bladed calcite cement (arrows) precipitated on saddle dolomite crystal: note the trace of calcite across saddle dolomite; such cement strongly refers to late meteoric alteration at near-surface condition. SD, Saddle dolomite; Dr, Dolomite recrystallization. 

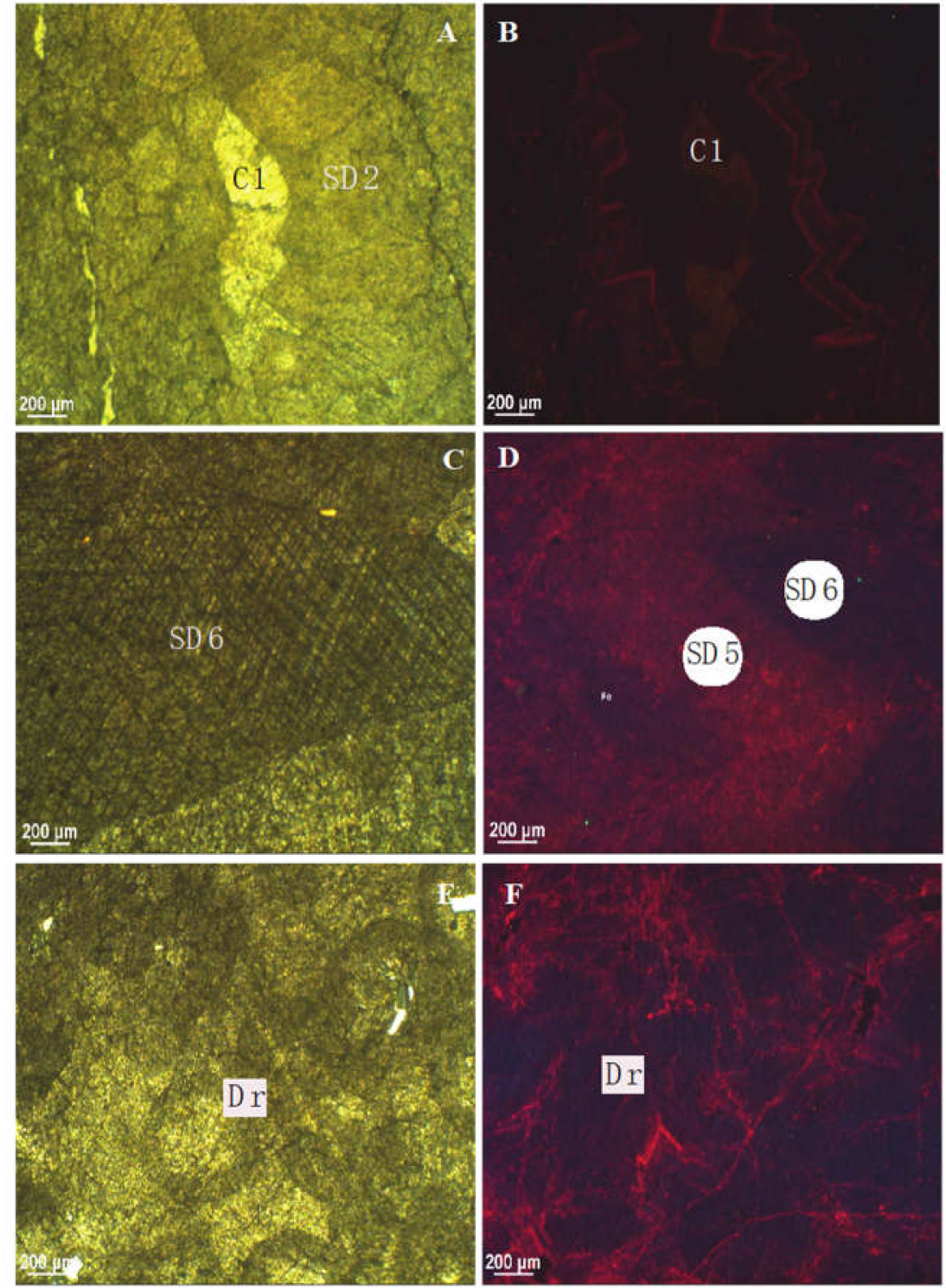

Figure 8. Photomicrograph of (A) saddle dolomite (SD2) and calcite (C1) in PPL, calcite overgrowth on the saddle dolomite is clearly highlighted under cathodoluminescence in (B). (C) Saddle dolomite (SD6) in PPL and (D) cathodoluminescence (CL) photomicrograph, illustrating the general pattern in luminescence, including thicker zones of red and nonluminescence with shades of thin bright red luminescence, reflecting formation in pore waters that chemically changed. (E) Recrystallized dolomite (Dr) in PPL, (F) the same as in (E) CL photomicrograph, the recrystallized dolomite shows thick nonluminescent zones with thin bright red luminescent bands.

A Fe-poor calcite cement $\left(\mathrm{C}_{\mathrm{J}}\right)$ fills the central parts of the fractures and vugs, hence the latest cement (Figure $8 \mathrm{~A}, \mathrm{~B})$. The calcite sizes are ranged from fine to coarse crystals $(>400 \mu \mathrm{m})$, precipitated and postdated saddle dolomite formation, and had crystals that were transparent with whitish and yellowish colors. CL revealed an alteration of thick red luminescence (SD5 $5_{\mathrm{J}}$ ) and thick nonluminescent SD6J (Figure 8B,C). In addition, thin bright red luminescence was associated with small veins and fractures that postdated SD6 J.

Dolomite recrystallization (Dr) occurred after all saddle dolomitic phases, where the ghosts of the pristine oolitic facies still resisted diagenesis, and in places the coarse sized poikilotopic cement fabric $(>700 \mu \mathrm{m})$ developed. Dr displays the same characteristics as those observed in SD6 $6_{\mathrm{J}}$ under $\mathrm{CL}$, i.e., nonluminescent thick with thin bright red luminescent bands (Figure 8E,F). 
Because of the small sizes of fractures and cavities, and also the fact that sometimes two dolomite phases occur together in a fracture during mixing the carbonate phases are categorized into four groups to obtain precise data: type 1 with $\mathrm{D}_{\mathrm{J}}, \mathrm{D} 1_{\mathrm{T}}$ and $\mathrm{D} 2_{\mathrm{T}}$; type II with saddle dolomites from $\mathrm{SD} 1_{\mathrm{T} / \mathrm{J}}$ and $\mathrm{SD} 2 \mathrm{~T} / \mathrm{J}$; type III with SD3 ${ }_{\mathrm{T} / \mathrm{J}}, \mathrm{SD} 4_{\mathrm{T}}, \mathrm{D} 4_{\mathrm{J}}, \mathrm{SD} 5_{\mathrm{T} / \mathrm{J}}, \mathrm{Dr}$, and SD6 $6_{\mathrm{J}}$ and type IV with $\mathrm{C} 1_{\mathrm{T} / \mathrm{J}}$. This phase succession will also make it easier to interpret the geochemical composition, especially when two carbonate phases are mixed.

\subsection{Early and Late Diagenetic Stylolites}

Most stylolites are used as a key of the burial depth, especially those aligned parallel to the bedding planes. The Triassic-Jurassic carbonate succession is characterized by two types of stylolites: (i) low amplitude stylolites (no more than $1 \mathrm{~cm}$ in length) crosscut Type I dolomites. The low amplitude stylolites (early stylolites) were the first ones produced during the Triassic-Jurassic diagenesis and are associated with a jump-up in McArthur's graph [19]; (ii) early stylolites are followed by larger stylolites (several centimeters in length with high amplitudes) associated with a set of fractures and tension gashes. Stylolite-related fractures (tension gashes) are rare diagenetic features formed by increasing and progressive mechanical loading during burial, evidenced by the parallel orientation with the bedding plane $[20,21]$.

\subsection{Chemical Composition (Major and Trace Elements)}

Nineteen samples were selected for trace element analyses from both outcrops (Table 1).

Table 1. Elemental analysis of diagenetic phases from Triassic and Jurassic samples $(n=19)$. Type $\mathrm{I}=\mathrm{D} 1_{\mathrm{T} / \mathrm{J}}$ and $\mathrm{D} 2_{\mathrm{T} / \mathrm{J}}$. Type II $=\mathrm{SD} 1_{\mathrm{T} / \mathrm{J}}$ and SD2 $\mathrm{T} / \mathrm{J}$. Type III $=\mathrm{SD} 3_{\mathrm{T} / \mathrm{J}}, \mathrm{SD} 4_{\mathrm{T}}, \mathrm{D} 4_{\mathrm{J}}, \mathrm{SD} 5_{\mathrm{T} / \mathrm{J}}$ $\mathrm{Dr}_{\mathrm{J}}$, and $\mathrm{SD} 6$. Type IV $=\mathrm{CT}_{\mathrm{T} / \mathrm{J}} . \mathrm{T}=$ Triassic, $\mathrm{J}=$ Jurassic, and Lst $=$ Host limestone. SE France sections.

\begin{tabular}{ccccccccc}
\hline $\begin{array}{c}\text { Sample } \\
\text { No. }\end{array}$ & Type & $\begin{array}{c}\text { Mn } \\
\text { (ppm) }\end{array}$ & $\begin{array}{c}\text { Fe } \\
\text { (ppm) }\end{array}$ & $\begin{array}{c}\text { Ba } \\
\text { (ppm) }\end{array}$ & $\begin{array}{c}\text { Sr } \\
\text { (ppm) }\end{array}$ & $\begin{array}{c}\text { Mg } \\
\text { (wt. \%) }\end{array}$ & $\begin{array}{c}\text { Ca } \\
\text { (wt. \%) }\end{array}$ & $\begin{array}{c}\text { Ca (wt. \%)/ } \\
\text { Mg (wt. \%) }\end{array}$ \\
\hline NM4 & Type III & 147 & 433 & 3 & 125 & 12.7 & 21.8 & 1.7 \\
NM8 & Type IV & 13 & 27 & 4 & 291 & 0.5 & 39.4 & 86.0 \\
NM10a & Type II & 34 & 152 & 3 & 60 & 12.8 & 21.9 & 1.7 \\
NM12 & Type II & 37 & 78 & 6 & 197 & 11.4 & 23.7 & 2.1 \\
NM16 & Type II & 108 & 317 & 4 & 134 & 12.1 & 22.7 & 1.9 \\
NM23 & Type I & 110 & 1991 & 2 & 73 & 12.4 & 21.5 & 1.7 \\
NM23 & Type III & 66 & 1076 & 2 & 106 & 11.9 & 22.7 & 1.9 \\
NM28 & Type I & 107 & 718 & 4 & 83 & 12.7 & 21.8 & 1.7 \\
NM30 & Type IV & 146 & 204 & 3 & 368 & 0.6 & 38.9 & 68.0 \\
NM34 & Type III & 91 & 282.3 & 2 & 86 & 11.5 & 23.4 & 2.0 \\
NM4 & Type III & 140 & 441 & 3 & 61 & 12.2 & 20.6 & 1.7 \\
NM21 & Type III & 226 & 730 & 4 & 180 & 11.9 & 21.8 & 1.8 \\
NM22 & Type III & 40 & 168 & 3 & 103 & 12.6 & 21.8 & 1.7 \\
NM11 & Type I & 51 & 463 & 2 & 83 & 11.4 & 22.1 & 1.9 \\
NM34 & Type III & 61 & 291 & 1 & 79 & 11.4 & 21.9 & 1.9 \\
NM32 & Type II & 60 & 337 & 2 & 47 & 12.3 & 21.2 & 1.7 \\
NM23 & Type III & 149 & 1225 & 8 & 257 & 10.8 & 23.1 & 2.1 \\
NM44 & Lst-Triassic & 113 & 1309 & 2 & 79 & 12.2 & 20.4 & 1.7 \\
NM39 & Lst-Jurassic & 10 & 154 & 3 & 127 & 0.3 & 37.8 & 135.5 \\
\hline
\end{tabular}

Generally, Ca (mean: 22.1 wt. \%; $n=15)$ and Mg (mean: 12 wt. \%; $n=15)$, Ca (mean: 39.2 wt. \%; $n=2)$ and $\mathrm{Mg}$ (mean: $0.6 \mathrm{wt} . \% ; n=2$ ) are the major elements in dolomite and calcite phases, respectively. Other elements like $\mathrm{Sr}$ (mean: $112 \mathrm{ppm} ; n=15$ for dolomite; mean: $330 \mathrm{ppm} ; n=2$ for calcite), Fe (mean: 580 ppm; $n=15$ for dolomite; mean: 116 ppm; $n=2$ for calcite), Mn (mean: $95 \mathrm{ppm} ; n=15$ for dolomite; mean: $180 \mathrm{ppm} ; n=2$ for calcite), Ba (mean: 3 ppm; $n=15$ for dolomite; mean: 4 ppm; $n=2$ for calcite), represent crucial "trace elements" in the carbonate diagenetic setting (Figure 9). The relative abundance of major elements and scarcity of trace elements in dolomite and calcite, are likely the recorded evidence of diagenetic processes (e.g., [22]). 


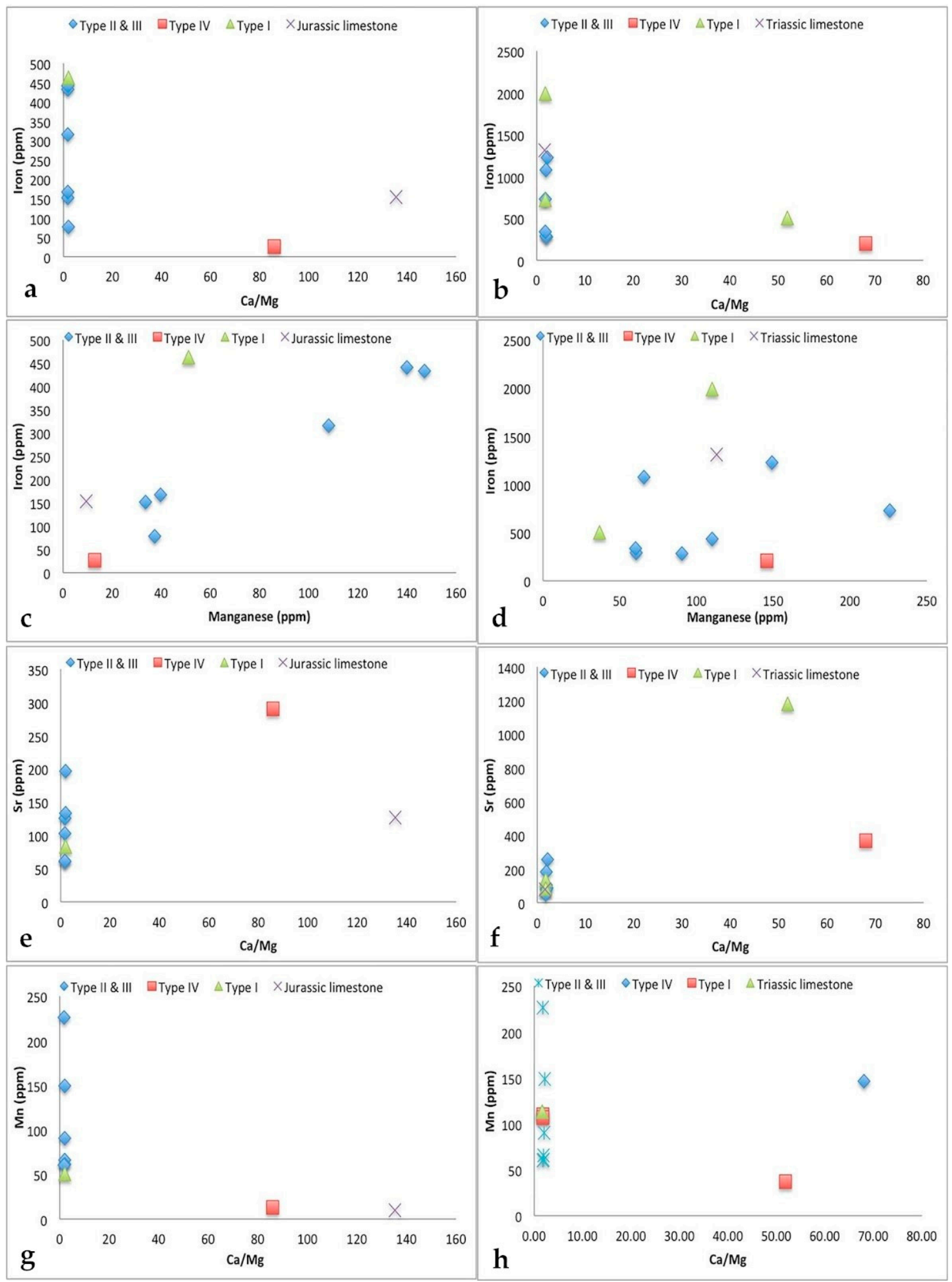

Figure 9. Diagram of the main chemical elements involved in the diagenesis and of the host limestones from the study area $(n=20)$. For more detail about Type I, II, III, IV, see text. (a) Ca/Mg vs. Fe for Jurassic carbonate samples, (b) Ca/Mg vs. Fe for Triassic carbonate samples, (c) Mn vs. Fe for Jurassic carbonate samples, (d) Mn vs. Fe for Triassic carbonate samples, (e) Ca/Mg vs. Sr for Jurassic carbonate samples, (f) Ca/Mg vs. Sr for Triassic carbonate samples, (g) Ca/Mg vs. Mn for Jurassic carbonate samples, and (h) $\mathrm{Ca} / \mathrm{Mg}$ vs. Mn for Triassic carbonate samples. 
The $\mathrm{Ca} / \mathrm{Mg}$ ratio of the saddle dolomites (Types II and III) ranges between 1.72 and 2.14 from the Triassic samples, and 1.69 and 2.08 from the Jurassic samples. The $\mathrm{Ca} / \mathrm{Mg}$ ratio of the late calcite phase in the Triassic is 68 and in the Jurassic is 85 (Figure 9). The Jurassic dolomites show a gradual increase in Fe and Mn, starting from 34 going up to $226 \mathrm{ppm}$ for $\mathrm{Mn}$, and 78 to $730 \mathrm{ppm}$ for Fe. The Triassic dolomites exhibit high Fe and Mn values (mean: 846 and 92 ppm, respectively), with a wide range. Rarely do the Mn contents of the early dolomites in both sections overlap the Mn contents of the later dolomites. The early dolomites display the highest Fe contents. The Fe and Mn contents in the Triassic and Jurassic limestones share the same values with a few late dolomite samples. In contrast, late calcite-Type IV $\left(\mathrm{C}_{\mathrm{J}}\right.$ and $\left.\mathrm{C}_{\mathrm{T}}\right)$ contents exhibit the lowest Fe contents $\left(\mathrm{C}_{\mathrm{T}}: \mathrm{Fe}=204 \mathrm{ppm} ; \mathrm{Mn}=146 \mathrm{ppm}\right)\left(\mathrm{C} 1_{\mathrm{J}}: \mathrm{Fe}=27 \mathrm{ppm} ; \mathrm{Mn}=13 \mathrm{ppm}\right)$. Higher Fe and Mn contents in $\mathrm{C1}_{\mathrm{T}}$ could be related to $\mathrm{SD} 3_{\mathrm{T}}$, which was overlain by the calcite cement, i.e., due to mixing of $\mathrm{SD} 3_{\mathrm{T}}$ and $\mathrm{C} 1_{\mathrm{T}}$ during preparation.

\section{5. $\delta^{18} O_{V P D B}$ and $\delta^{13} C_{V P D B}$ Isotopes}

The stable isotopic compositions of ten limestone samples (Table 2) shows that the $\delta^{18} \mathrm{O}_{\mathrm{VPDB}}$ and $\delta^{13} C_{\text {VPDB }}$ values vary between $-0.2 \%$ o to $-4.2 \%$ o and $-0.5 \%$ o to $+3.1 \%$ o, respectively. The isotopic composition of the four dolomite types (I, II, III and IV) shows a range in $\delta^{13} \mathrm{C}_{\mathrm{VPDB}}$ values from $-0.6 \%$ to $+2.6 \%$ and $\delta^{18} \mathrm{O}_{\mathrm{VPDB}}$ values from $-14.1 \%$ o to $-4.9 \%$. In more detail, the $\delta^{18} \mathrm{O}_{\mathrm{VPDB}}$ values of Type I $\left(\mathrm{D} 1_{\mathrm{T} / \mathrm{J}}\right.$ and $\left.\mathrm{D} 2_{\mathrm{T} / \mathrm{J}}\right)$ display a narrow range between $-7.1 \%$ and $-4.8 \%$ in the Jurassic and from $-7.4 \%$ to $-5.7 \%$ in the Triassic. The $\delta^{13} C_{V P D B}$ values for both sections display similar values (average $+1.1 \%$ o and $+1.9 \%$, respectively). All $\delta^{18} \mathrm{O}_{\mathrm{VPDB}}$ values are depleted in comparison with the original isotopic compositions of the marine dolomite signature during Triassic and Jurassic times [22-25].

Table 2. $\delta^{13} \mathrm{C}(\% \mathrm{VPDB}), \delta^{18} \mathrm{O}(\% \mathrm{VPDB}),\left(\mathrm{Sr}^{87} / \mathrm{Sr}^{86}\right)$ values of selected samples from Triassic-Jurassic succession $(n=100)$. Type $\mathrm{I}=\mathrm{D} 1_{\mathrm{T} / \mathrm{J}}$ and $\mathrm{D} 2_{\mathrm{T} / \mathrm{J}}$. Type II $=\mathrm{SD} 1_{\mathrm{T} / \mathrm{J}}$ and SD2 $\mathrm{T} / \mathrm{J}$. Type III $=\mathrm{SD} 3_{\mathrm{T} / \mathrm{J}}, \mathrm{SD} 4_{\mathrm{T}}$, $\mathrm{D}_{\mathrm{J}}, \mathrm{SD}_{\mathrm{T} / \mathrm{J}}, \mathrm{Dr}{ }_{\mathrm{J}}$, and SD6. Type IV $=\mathrm{CT} 1_{\mathrm{T} / \mathrm{J}} . \mathrm{D}$ is for dolomite, $\mathrm{SD}=$ saddle dolomite, $\mathrm{C}=$ calcite, $\mathrm{Dr}=$ recrystallized dolomite $\mathrm{T}=$ Triassic, $\mathrm{J}=\mathrm{Jurassic}$, and Lst $=$ Host limestone. SE France sections.

\begin{tabular}{|c|c|c|c|c|c|}
\hline \multirow{2}{*}{ Age } & \multirow{2}{*}{ Sample No. } & \multirow{2}{*}{ Type } & \multirow{2}{*}{$\frac{\delta^{13} \mathrm{C}}{(\% \circ \mathrm{VPDB})}$} & \multirow{2}{*}{$\begin{array}{c}\delta^{18} \mathrm{O} \\
(\% \text { o VPDB })\end{array}$} & \multirow{2}{*}{$\mathrm{Sr}^{87} / \mathrm{Sr}^{8 \mathrm{C}}$} \\
\hline & & & & & \\
\hline \multirow{23}{*}{ Upper Jurassic } & NM1 & Type III & 1.72 & -9.09 & \\
\hline & NM2 & Type II & 1.78 & -8.25 & \\
\hline & NM3 & Type III & 1.46 & -9.35 & \\
\hline & NM3 & Type III & 1.78 & -9.94 & \\
\hline & NM3 & Type II & 2.06 & -8.03 & \\
\hline & NM4 & Type I & 1.81 & -6.44 & \\
\hline & NM5 & Type I & 1.74 & -7.07 & \\
\hline & NM5 & Type II & 1.76 & -7.85 & \\
\hline & NM5 & Type III & 1.83 & -9.99 & \\
\hline & NM6 & Type I & 2.04 & -4.87 & \\
\hline & NM7 & Type III & 1.69 & -9.82 & \\
\hline & NM7 & Type III & 1.72 & -9.43 & \\
\hline & NM7 & Type III & 1.72 & -9.83 & \\
\hline & NM8 & Type III & 1.81 & -8.75 & \\
\hline & NM8 & Type III & 1.63 & -9.61 & \\
\hline & NM8 & Type IV & 0.38 & -11.83 & 0.70868 \\
\hline & NM9 & Type III & 1.81 & -10.86 & \\
\hline & NM10a & Type II & 1.55 & -8.02 & 0.71030 \\
\hline & NM10b & Type II & 1.44 & -8.18 & 0.710552 \\
\hline & NM11 & Type III & 1.48 & -10.78 & \\
\hline & NM11 & Type III & 2.07 & -10.56 & \\
\hline & NM12 & Type III & 1.78 & -9.14 & \\
\hline & NM13 & Type III & 1.76 & -9.28 & \\
\hline
\end{tabular}


Table 2. Cont.

\begin{tabular}{|c|c|c|c|c|c|}
\hline Age & Sample No. & Type & $\frac{\delta^{13} \mathrm{C}}{(\% \circ \mathrm{VPDB})}$ & $\frac{\delta^{18} \mathrm{O}}{(\% \text { o VPDB })}$ & $\mathrm{Sr}^{87} / \mathrm{Sr}^{86}$ \\
\hline \multirow{21}{*}{ Upper Jurassic } & NM14 & Type IV & -0.59 & -11.12 & \multirow{3}{*}{0.710355} \\
\hline & NM14 & Type IV & -0.02 & -9.98 & \\
\hline & NM15 & Type III & 1.85 & -9.42 & \\
\hline & NM15 & Type III & 1.86 & -9.71 & 0.710154 \\
\hline & NM16 & Type I & 1.76 & -6.31 & \multirow[t]{7}{*}{0.708757} \\
\hline & NM16 & Type III & 1.42 & -9.65 & \\
\hline & NM17 & Type III & 1.79 & -9.31 & \\
\hline & NM17 & Type III & 1.8 & -9.47 & \\
\hline & NM18 & Type IV & 0.92 & -10.42 & \\
\hline & NM18 & Type III & 1.59 & -10.26 & \\
\hline & NM18 & Type III & 1.57 & -9.66 & \\
\hline & NM19 & Type III & 1.57 & -9.72 & \multirow[t]{5}{*}{0.711203} \\
\hline & NM19 & Type III & 1.48 & -9.23 & \\
\hline & NM20 & Type IV & 0.98 & -9.62 & \\
\hline & NM20 & Type IV & -0.15 & -10.52 & \\
\hline & NM20 & Type III & 1.29 & -9.31 & \\
\hline & NM21 & Type III & 1.61 & -11.63 & \multirow{2}{*}{0.710609} \\
\hline & NM21 & Type I & 1.98 & -6.82 & \\
\hline & NM22 & Type III & 1.82 & -9.05 & \multirow[t]{3}{*}{0.708879} \\
\hline & NM22 & Type III & 1.84 & -9.45 & \\
\hline & NM22 & Type III & 1.83 & -9.37 & \\
\hline \multirow{27}{*}{ Triassic } & NM23 & Type II & 2.3 & -6.2 & \\
\hline & NM23 & Type II & 2.3 & -6.8 & \\
\hline & NM24 & Type III & 2.3 & -9.98 & \\
\hline & NM24 & Type III & 1.97 & -9.09 & \\
\hline & NM25 & Type III & 2.56 & -9.86 & \\
\hline & NM27 & Type II & 2.31 & -7.58 & \\
\hline & NM27 & Type III & 2.21 & -8.28 & \multirow[t]{3}{*}{0.708299} \\
\hline & NM27 & Type II & 2.21 & -7.48 & \\
\hline & NM26 & Type I & 1.98 & -5.7 & \\
\hline & NM26 & Type I & 1.31 & -6.44 & \multirow[t]{3}{*}{0.707735} \\
\hline & NM28 & Type III & 2.54 & -8.51 & \\
\hline & NM28 & Type III & 1.46 & -9.35 & \\
\hline & NM29 & Type II & 2.2 & -6.67 & 0.708671 \\
\hline & NM30 & Type IV & 0.65 & -14.14 & \multirow[t]{5}{*}{0.712023} \\
\hline & NM31 & Type III & 2.11 & -8.44 & \\
\hline & NM32 & Type III & 2.2 & -8.57 & \\
\hline & NM32 & Type III & 2.02 & -9.91 & \\
\hline & NM33 & Type III & 2.49 & -8.74 & \\
\hline & NM33 & Type III & 2.03 & -9.44 & \multirow[t]{3}{*}{0.70942} \\
\hline & NM34 & Type III & 1.81 & -9.63 & \\
\hline & NM34 & Type II & 1.97 & -7.93 & \\
\hline & NM34 & Type III & 2 & -9.16 & \multirow[t]{3}{*}{0.708184} \\
\hline & NM35 & Type III & 2.26 & -9.07 & \\
\hline & NM35 & Type IV & 2.09 & -12.08 & \\
\hline & NM36 & Type I & 0.21 & -7.35 & 0.708595 \\
\hline & NM36 & Type I & 0.93 & -7.35 & 0.711628 \\
\hline & NM37 & Type III & 1.16 & -10.35 & 0.710469 \\
\hline \multirow{2}{*}{ Upper Jurassic } & NM38 & Limestone & 2.07 & -2.33 & \multirow[b]{2}{*}{0.707862} \\
\hline & NM39 & Limestone & -0.53 & -4.21 & \\
\hline
\end{tabular}


Table 2. Cont.

\begin{tabular}{|c|c|c|c|c|c|}
\hline Age & Sample No. & Type & $\frac{\delta^{13} \mathrm{C}}{(\% \circ \mathrm{VPDB})}$ & $\frac{\delta^{18} \mathrm{O}}{(\% \text { VPDB })}$ & $\mathrm{Sr}^{87} / \mathrm{Sr}^{86}$ \\
\hline \multirow{8}{*}{ Triassic } & NM40 & Limestone & 1.54 & -2.31 & \multirow{8}{*}{0.708766} \\
\hline & NM41 & Limestone & 1.73 & -2.5 & \\
\hline & NM42 & Limestone & 1.88 & -3.36 & \\
\hline & NM43 & Limestone & 1.98 & -1.67 & \\
\hline & NM44 & Limestone & 2.53 & -2.37 & \\
\hline & NM45 & Limestone & 2.31 & -3.36 & \\
\hline & NM46 & Limestone & 3.05 & -0.23 & \\
\hline & NM47 & Limestone & 2.71 & -3.25 & \\
\hline
\end{tabular}

The $\delta^{18} \mathrm{O}_{\mathrm{VPDB}}$ values of Type II dolomite show a signature with depleted values varying between $-8.3 \%$ ond $-7.9 \%$ in the Jurassic samples, and from $-7.9 \%$ o to $-6.2 \%$ o in the Triassic samples. These $\delta^{18} \mathrm{O}_{\mathrm{VPDB}}$ values of saddle dolomites decrease with the increase in crystal size. The $\delta^{13} \mathrm{C}$ values of Type II and Type III exhibit a narrow range in the Triassic (average $+2.0 \%$ o and $+2.4 \%$ o) and in the Jurassic (average $+1.7 \%$ ond $+1.9 \%$ o). Type IV late-stage calcite shows significantly depleted $\delta^{18} \mathrm{O}_{\mathrm{VPDB}}$ values in the Triassic ( $-14.1 \%$ o and $-12.1 \%$ ) and in the Jurassic (between -11.8 and $-9.6 \%$ ).

4.6. ${ }^{87} \mathrm{Sr} /{ }^{86} \mathrm{Sr}$ Data

The ${ }^{87} \mathrm{Sr} /{ }^{86} \mathrm{Sr}$ data of dolomite and calcite (Table 2) in the Triassic section show a wide range ( 0.707735 and 0.712023$)$, while in the Jurassic section the range is between 0.708680 and 0.71120 , so the ratios are lower than those of the host limestone sample.

The two unaltered limestone samples yielded an ${ }^{87} \mathrm{Sr} /{ }^{86} \mathrm{Sr}$ ratio of 0.708766 and 0.707862 for the Triassic and Jurassic limestones, respectively. The Triassic signal displays a value different from the seawater signal when compared to the data of Korte et al. [26], which reported the ${ }^{87} \mathrm{Sr} /{ }^{86} \mathrm{Sr}$ values between 0.707562 and 0.70804 . Jurassic samples have been documented by Jones et al. [27] with an $\mathrm{Sr}^{87} / \mathrm{Sr}^{86}$ ratio in the range of $0.707060-0.707280$.

\section{Interpretation and Discussion}

\subsection{Paragenetic Sequence Related to Dolomitizing Fluids}

The petrographic and geochemical data obtained suggest that dolomitization has been accomplished by various episodes of hydrothermal flow events under various burial diagenetic conditions. The earliest dolomitization, which affected mainly the micrite mud matrix, probably occurred at near-surface conditions. This is evidenced by the anhedral, non-saddle dolomite fabric [28] and the uncompacted ooids. The nonplanar crystal shape of dolomite Type I D2 $\mathrm{T}$ could be linked to a diagenesis at a higher temperature (e.g., $\geq 50^{\circ} \mathrm{C}$, [28]). However, these nonplanar dolomites are probably related to impurities in the growth media, which stabilize the crystal faces [29], and not to high temperature fluids. This is supported by petrographic evidence-for example, $\mathrm{D} 2{ }_{\mathrm{T}}$ crystals do not show any characteristics of hot fluid involvement "i.e., lack of curved faces and sweeping extinction".

It is well reported in the literature that saddle dolomite forms under high temperatures typically by flow of hydrothermal fluids [30]. Type II is dissolved by low-amplitude, early stylolites, in high temperature conditions (senso, [31]) in the shallow-intermediate depth without necessarily implying deep burial conditions "i.e., eogenesis".

Brecciation and concomitant dolomitization (Type II dolomites) suggest a flow of hydrothermal fluids along fractures (Figure 10). Brecciation was accompanied by the dissolution of the host carbonates, which resulted in the creation of new pathways for fluid of hydrothermal fluids and cementation by producing the Type III saddle dolomite. Further cementation by the latter dolomite was probably related to hydrofracturing and resetting of the zebra and breccia fabrics. Stylolite-related fractures are 
parallel to the amplitude of stylolite (Figure 4F), and according to Nelson [20] the tension gashes are not true tension fractures, but are extensional fractures derived from the same compressive state of stress as the fractures of stylolites [32]. Filling the tension gash fractures with SD3 confirmed that the late stylolites are coeval with Type III saddle dolomite formation (Figures 11 and 12). Stylolite-related fractures (tension gashes), which were produced during deep burial mesogenesis, were cemented by Type III saddle dolomite (Figure 4F). Hence, Type III saddle dolomite formation was presumably formed by the flux of hot basinal fluids along stylolites during compressional basin tectonics [33].

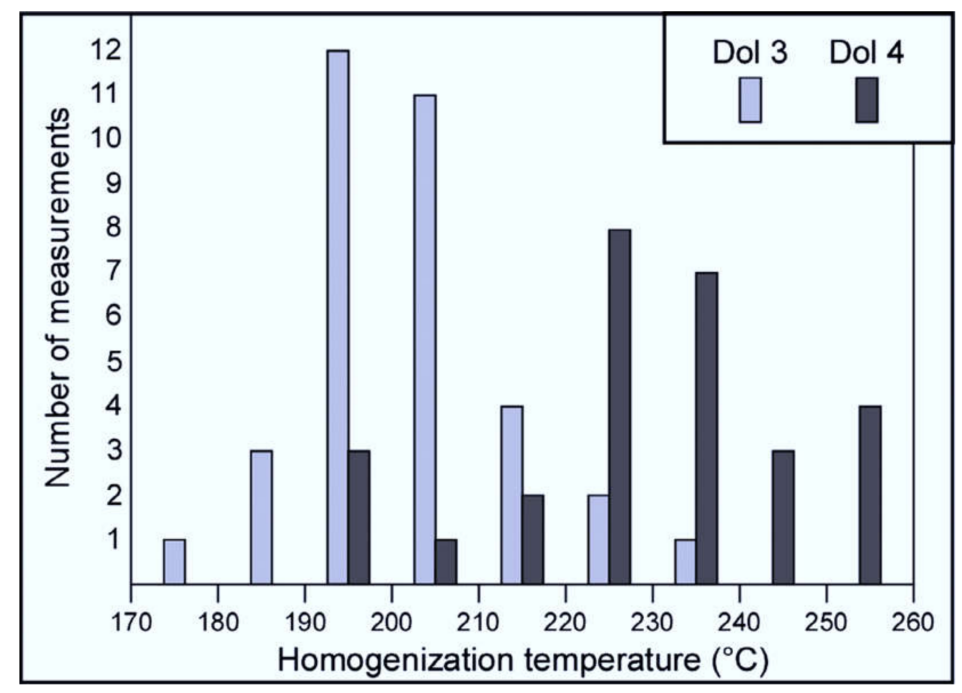

Figure 10. Histogram of homogenization temperatures obtained for saddle dolomite and fibrous dolomite cements [14].

\begin{tabular}{|c|c|c|c|c|}
\hline $\begin{array}{lll}\text { Phase } & \text { Stage } \\
\end{array}$ & Near-surface realm & Shallow-burial realm & $\begin{array}{c}\text { Intermediat-deep-burial } \\
\text { realm }\end{array}$ & $\begin{array}{c}\text { Telogenetic and uplifting } \\
\text { realm }\end{array}$ \\
\hline \multicolumn{5}{|l|}{ Crystalline micrite (MT) } \\
\hline \multicolumn{5}{|l|}{ Replacive dolomite (D1T) } \\
\hline $\begin{array}{l}\text { Neomorphic dolomite } \\
\text { (D2T) }\end{array}$ & & & & \\
\hline Fracturing I-SD1T, SD2T & & & $=$ & \\
\hline Early stylolization & - & & $=$ & \\
\hline $\begin{array}{l}\text { Fracturing II-Enlargement } \\
\text { SD3T }\end{array}$ & & & $=-$ & \\
\hline $\begin{array}{l}\text { Late stylolization and } \\
\text { tension fractures, SD } 3 \mathrm{~T}\end{array}$ & & $=$ & & \\
\hline Saddle dolomites (SDT4) & & & & \\
\hline $\begin{array}{l}\text { Dedolomitization and } \\
\text { calcite precipitation, } \mathrm{C} 1 \mathrm{~T}\end{array}$ & & & & \\
\hline
\end{tabular}

Figure 11. Paragenetic succession illustrating the diagenetic phases of Triassic section. Provençal Domain, SE France (see text for explanation). 


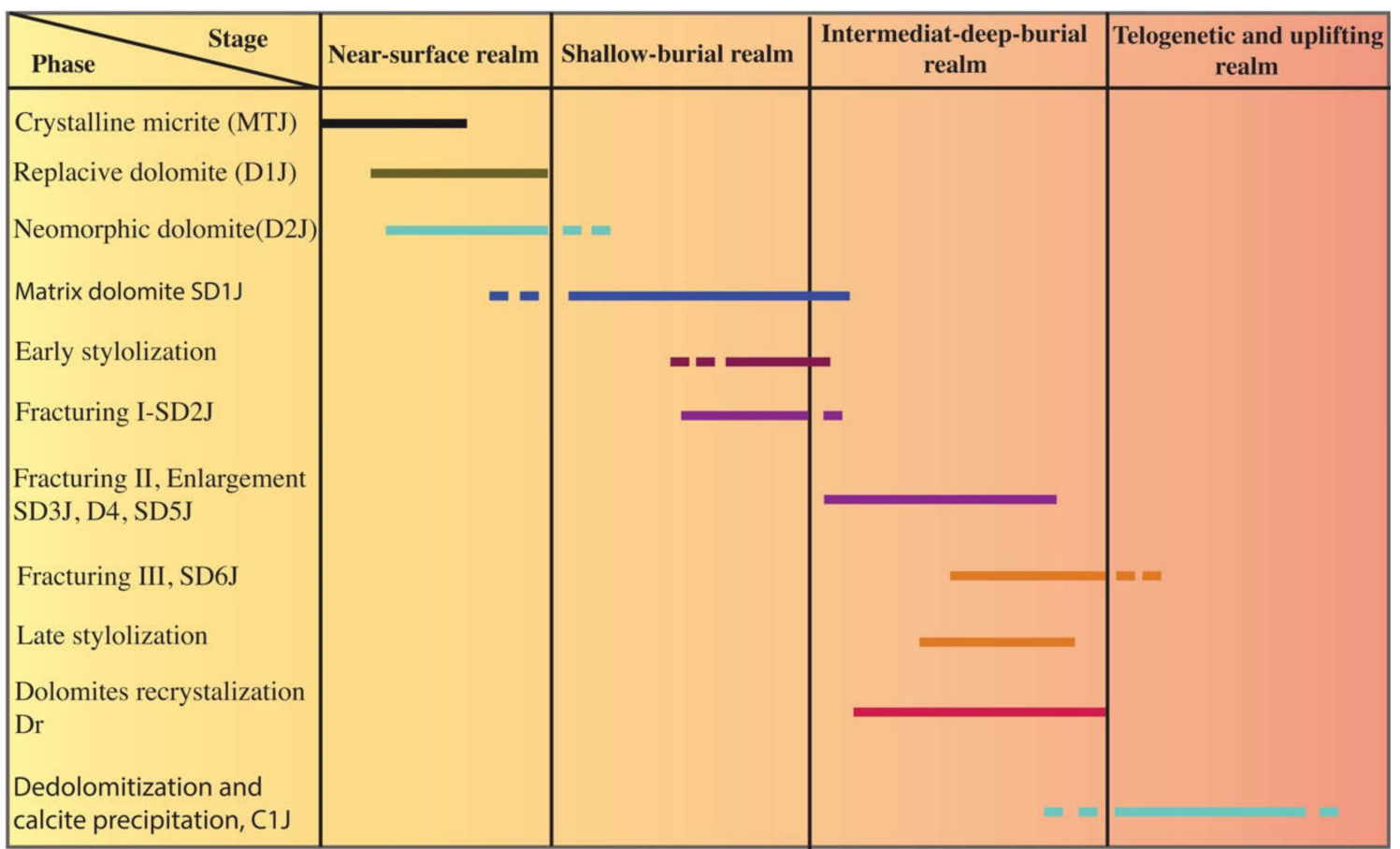

Figure 12. Paragenetic succession illustrating the diagenetic phases of Jurassic section. Provençal Domain, SE France (see text for explanation).

Subsequent openings of the veins or fractures in Type II facies led the hot secondary brine fluid to percolate along these pathways, which resulted in the precipitation of Type III saddle dolomites. The hydrothermal activity associated with hydrofracturing affecting the studied Mesozoic series has also been reported by [34-36].

The homogenization temperature of saddle dolomites from the Dauphinois-Provençal Domains varied between 170 and $260^{\circ} \mathrm{C}$ ([14]; Figure 10), which rules out a low temperature origin for dolomite. The final melting temperature of fluid inclusions have been reported as highly saline fluids, and the salinity was approximately equivalent to $20 \%$ to $23 \% \mathrm{CaCl}_{2}$ [14], this confirms the interaction of hot circulating fluids with Argentera basement. The high temperature dolomitizing fluid is further supported by low $\delta^{18} \mathrm{O}_{\mathrm{VPDB}}$ values. The depletion of the $\delta^{18} \mathrm{O}_{\mathrm{VPDB}}$ values follows the increase in the size of saddle crystal from Type II to Type III (up to $-11.6 \%$ in Type III dolomites). Therefore, the plausible explanation that can adequately explain the range of homogenization temperatures and considerable range of oxygen isotope values is that the precipitation of dolomite phases occurred at different diagenetic settings during which a repeated injection of hydrothermal fluid occurred (Figures 13 and 14). This interpretation is further supported by the following lines of evidence (Figures 4 and 6): (1) suture intergranular contacts between the ooids are engulfed by the saddle dolomite cement; (2) occurrence of sulfides and dissolution of stylolite-related fractures in type III saddle dolomites; (3) co-occurrence of Type III saddle dolomites and late stylolite-related fractures, later the cements inside the fractures were dissolved and etched; (4) coarse-crystalline poikilotopic cement fabric $(>700 \mu \mathrm{m})$ etched and corroded the Dr boundaries; (5) dissolution, compacted saddle dolomite and association with sulfides; (6) the presence of high-amplitude stylolites parallel to the overburden force. 


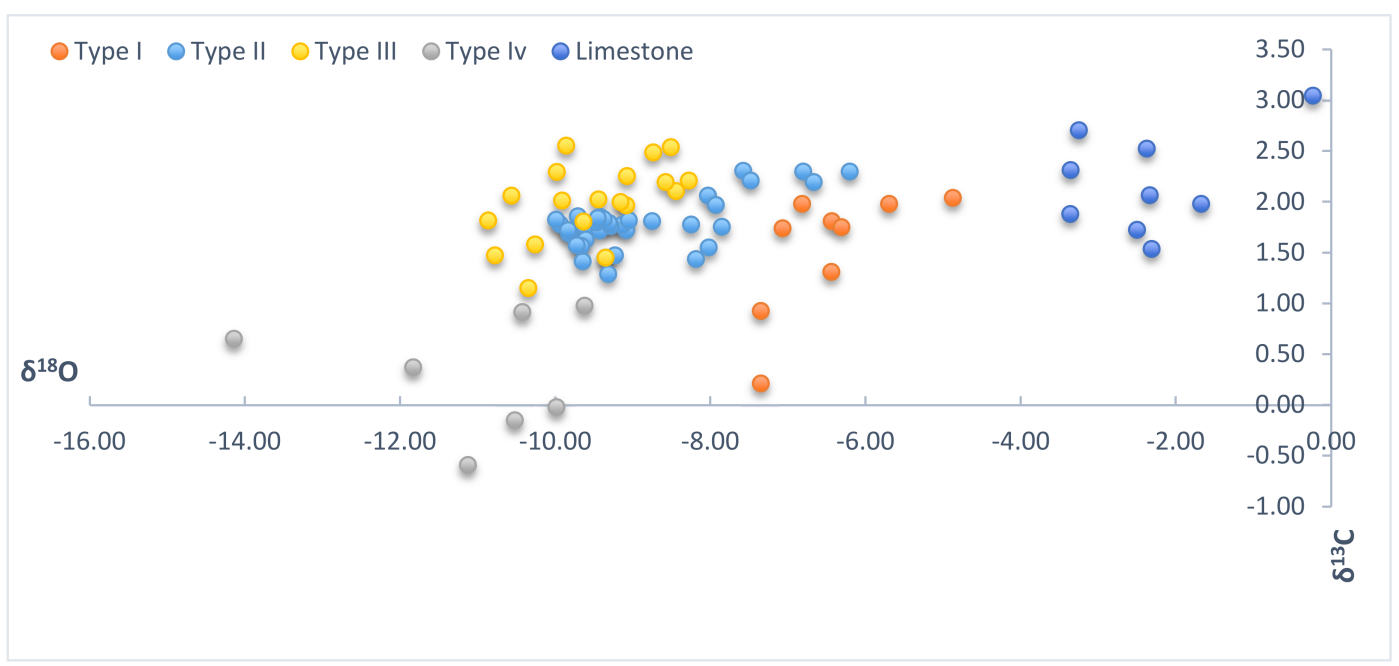

Figure 13. Cross-plot of oxygen and carbon isotopic compositions (VPDB) of selected dolomite, calcite phases (Type I to IV: see text) and pristine limestone from Triassic-Jurassic succession $(n=80)$.

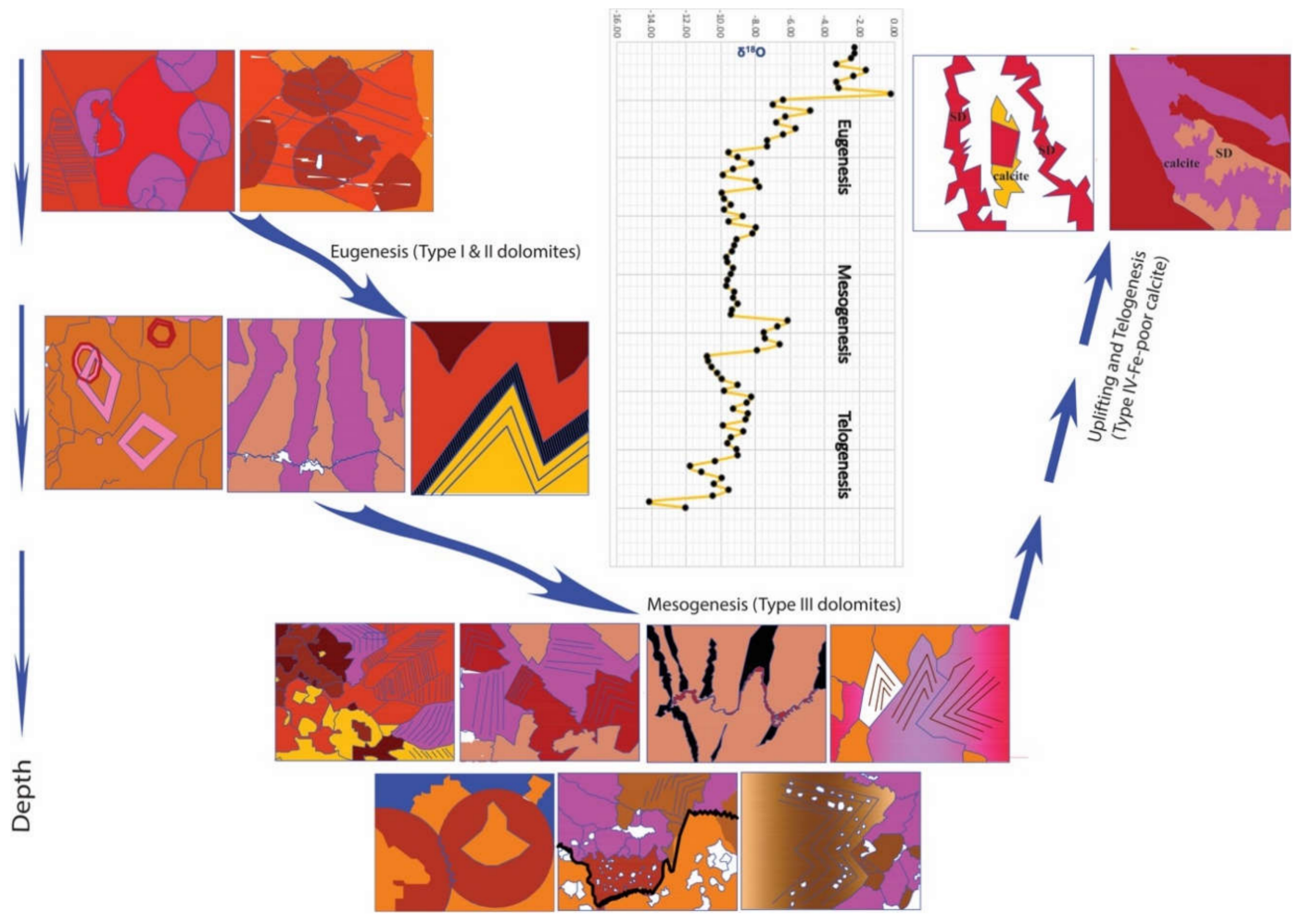

Figure 14. Petro-physical and geochemical model tracing the Triassic-Jurassic succession in Provençal Domain, SE France. The detailed microfacies in each diagenetic setting is described by digitized microphotographs under optical microscope. The initial precipitation of saddle dolomite is started in a shallow burial system (see the key evidence in digitized microphotographs). The mechanisms of hydrothermal (HT) fluid movement under deep burial conditions (mesogenesis) created another active pathway for hot fluid with different phase of saddle dolomite (see the zoned saddle dolomites, suture contact boundaries between the ooid grains, and stylolite-related fractures) from that of shallow burial conditions (see the low amplitude stylolite). The diagenesis in the Triassic-Jurassic succession ended by precipitation of Fe-poor calcite during uplifting (close up the large fracture that postdates all saddle phases on the right side of digitized microphotograph, while the one on the left side showing the digitized thin section under CL which result in a band of luminescence due to a change in fluid chemistry. 
Therefore, according to the abovementioned points, our interpretation agrees with the one of Wierzbicki et al. [37], who suggested that the partial dissolution of dolomite crystal outlines fits the deep burial mesogenesis. This late evolution could be linked to the subsidence and recrystallization processes in the Provençal Domain during Late Cretaceous-Early Eocene times, where the main extensional and transtensional tectonics affected the European paleomargin of the Alpine Tethys [38].

The calcitization of saddle dolomite and the precipitation of the fracture-filling Fe-poor calcite cement $\left(\mathrm{C}_{\mathrm{T} / \mathrm{J}}\right.$, Type IV; Figure 14), which cross cut the high-amplitude stylolites, are the last diagenetic event affecting the Triassic series by the incursion of meteoric waters. Furthermore, the precipitation of bladed calcite cement around saddle crystals implies that a new activity led to the uplift of the studied series and could reactivated the Alpine transcurrent shear zone during Cenozoic [39].

\subsection{Geochemical Evolution of Diagenetic Fluids}

A crucial question in any study of carbonate chemical composition is whether a primary marine signal is preserved or not. Carbon and oxygen isotopic compositions of the regional limestones span a considerable range with $\delta^{13} \mathrm{C}$ values between $-0.5 \%$ ond $+3.1 \%$ ond $\delta^{18} \mathrm{O}_{\mathrm{VPDB}}$ values between $-4.2 \%$ and $0.2 \%$ o. Their isotopic compositions are similar to the values expected for Triassic and Jurassic marine carbonates [23-27].

Type I dolomite and the last event of calcite precipitation (Type IV) have considerably lighter $\delta^{18} \mathrm{O}_{\mathrm{VPDB}}$ compared to those expected for the carbonate precipitated in equilibrium with ambient seawater (Figure 13). The $\delta^{18} \mathrm{O}$ and $\delta^{13} \mathrm{C}$ values in both types of dolomite and calcite fit the inverse " $\mathrm{J}$ " Lohmann curve [40] pointing to a diagenetic alteration near surface conditions. The initial nucleation of dolomite in the muddy facies was therefore driven by dolomite supersaturation caused by the mixing of fresh and marine groundwater [40-42]. Mixed groundwater filled the pore spaces in the oolite facies and led to undersaturation of calcite, and the dissolution and precipitation of dolomite in the case of Type I dolomite. The Triassic and Jurassic rocks developed on a shelf in which the water depth was extremely shallow, probably a few meters deep, as suggested by the oolites and algae. In such a shallow depositional setting these carbonates were probably altered and dolomitized by mixed water, as no evaporitic minerals were observed in this study. In the Triassic and Jurassic sections, the $\delta^{18} \mathrm{O}_{\mathrm{VPDB}}$ shifts toward a lower value in comparison with the original depositional facies, are quite abrupt and vary around their respective average ( $-6.7 \%$ and $-6.4 \%$ o) in the range of the "meteoric" [3]. The strong deviation in $\delta^{13} C_{V P D B}$ values from this line is related to the rock-water interaction in the Type I Triassic samples. Very weak variations or near constant $\delta^{13} C_{V P D B}$ values in the Type I Jurassic samples suggest decreased rock-water interactions in a distal setting from the meteoric recharge with a consequent buffering by the rocks.

Types II and III have depleted $\delta^{18} \mathrm{O}$ values (up to $-10.4 \%$ o for Type III in the Triassic and up to $-11.6 \%$ for Type III in the Jurassic) with more or less constant $\delta^{13} C_{\text {VPDB }}$ values in the Jurassic (Types II and III) and a wider range of $\delta^{13} \mathrm{C}_{\mathrm{VPDB}}$ values in Type III in the Triassic. The $\delta^{13} \mathrm{C}$ values are similar to the ones of the early dolomitic facies suggesting that the saddle dolomitizing fluid was mainly buffered by interactions with early dolomite rocks (Type I). The same buffered system has been inferred from our trace element analyses and showed that positive and gradual variation in $\mathrm{Fe}$ and $\mathrm{Mn}$ contents observed between Types II and III saddle dolomites due to water-rock interactions (Figure 13).

The significant shift to lower $\delta^{18} \mathrm{O}_{\mathrm{VPDB}}$ values from Type II to Type III in both sections is probably due to the interaction of the dolomitized rocks (Type I) with hydrothermal fluids (e.g., [12,43]). Similar carbon and oxygen isotopic values $(-9.0 \%$ o to $-7.3 \%$ o and $+1.8 \%$ o to $+2.4 \%$, respectively) were reported by Nader et al. [42] in the Jurassic rocks at Lebanon as the result of hydrothermal hot fluids under deep conditions. The tension-gashed stylolitization phase during the saddle emplacement between Type II and Type III saddle dolomites suggests that the chemical compaction or burial was coeval with the late phase of hot fluids (Type III dolomite). This phase is associated the most widespread depleted $\delta^{18} \mathrm{O}_{\mathrm{VPDB}}$ values (Figure 14). Triassic Type II facies show some similarities and overlapping $\delta^{18} \mathrm{O}_{\mathrm{VPDB}}$ values, such as those of Type I, suggesting that saddle precipitation started in the same 
burial conditions of the latter, but after early stylolitization. These complex scenarios of paragenetic models show that Types II and III correspond to complex polyphased dolomitizing fluids and Type III saddle dolomite was precipitated under deep burial-mesogenetic diagenesis. Their geometries (irregular, strata-discordant, zebras, even faults on the field) may suggest that the faults constituted a hydrothermal fluid conduit operating during two major steps with increasingly ${ }^{18} \mathrm{O}_{\mathrm{VPDB}}$ depleted values in the saddles as evidenced by two different isotopic domains in both sections. Further evidence for deep burial setting and mesogenesis includes the dissolution of saddle dolomite along stylolites (e.g., [44]) and sutured intergranular contacts between ooids.

Type IV Fe-poor calcite records a dedolomitization and cementation by similar calcite due to the incursion of meteoric waters $[40,45]$. The wide variations of the $\delta^{18} \mathrm{O}_{\mathrm{VPDB}}$ and $\delta^{13} \mathrm{C}_{\mathrm{VPDB}}$ values reveals an inverse "J" Lohmann curve $[40,45]$, at least in the Jurassic and probably in the Triassic, supporting a telogenetic meteoric origin. The $\delta^{18} \mathrm{O}_{\mathrm{VPDB}}$ and $\delta^{13} \mathrm{C}_{\mathrm{VPDB}}$ values from calcite samples overlap with the values of the HT dolomite; a similar situation has been reported from NW Spain by Shah et al. [46] and Nader et al. [42] in Lebanon on hydrothermal-hosted Jurassic rocks. These authors concluded that the wide range of depleted isotopic oxygen values with a slight shift in the isotopic carbon values of pristine facies indicate different temperatures of the dolomitizing fluids, while the extra-shifted carbon isotope values and highly depleted isotopic oxygen values in the calcite facies indicate surface-derived fluids. The abrupt Fe and Mn drops, Sr rise and weak Mn variations only reported in the Triassic samples that could be related to the $\mathrm{SD} 3$ overgrowth by $\mathrm{C} 1_{\mathrm{T}}$ suggest a significant lack in carbonate-buffering system. In addition, the saddle dolomitic contribution to calcite oxygen contents is very low compared to the contribution of the meteoric fluids [46] due to high $\delta^{18} \mathrm{O}_{\text {water }} / \delta^{18} \mathrm{O}_{\text {rock }}$ ratios. These arguments support that the calcite cement marks the end-member of the diagenetic sequence as a result of a late uplift of the carbonate platform, which initiated this late telogenetic phase (Figure 14).

\subsection{Impact of Basement-Fluid Interactions, Continental Riverine and vceanic Fluxes on Strontium Isotope Signatures}

Multiple parameters controlling the radiogenic strontium isotope in carbonate rocks, including: (i) the isotopic composition of seawater from which they precipitated and terrigenous (i.e., siliciclastics) sedimentary rocks; (ii) the ${ }^{87} \mathrm{Sr} /{ }^{86} \mathrm{Sr}$ ratio is mainly related to the nature of the parent rocks and their continental weathering rates (riverine) and oceanic fluxes of nonradiogenic strontium. However, diagenesis will be the main factor controlling the significant variation of the ${ }^{87} \mathrm{Sr} /{ }^{86} \mathrm{Sr}$ ratio in marine carbonates as it will be affected by hydrothermal or cold fluids that control the strontium ratio.

${ }^{87} \mathrm{Sr} /{ }^{86} \mathrm{Sr}$ in dolomites (Types I, II, III) vary from 0.707735 and 0.712023 in the Triassic and from 0.708680 up to 0.711203 in the Jurassic (Figure 15). These ratios are associated to the early and late stylolites, prior to the latest deformation during the uplift (Figure 14). The ${ }^{87} \mathrm{Sr} /{ }^{86} \mathrm{Sr}$ ratios are higher than those of ambient Triassic and Jurassic seawater [26,27]. A few of these ratios in the Triassic dolomites are lower than those of the marine carbonate obtained from host limestone samples $(0.708766$; Figure 15), while in the Jurassic dolomites the ratios are higher than those in the marine carbonate samples (0.707862; Figure 15).

When comparing our radiogenic values with the ones of the Triassic ${ }^{87} \mathrm{Sr} /{ }^{86} \mathrm{Sr}$ signals of the Lombardic Alps, the strontium values of the Lombardic Alps increased from 0.70805 in the Anisian to 0.708148 in the Ladinian as a result of the various rates of weathering and erosion of young volcanic rocks and old granitic rocks [47], are lower than our values in Provençal Domain (0.708766; Figure 15). Thus, it is more likely that an increase in the riverine flux was the dominant factor causing the ${ }^{87} \mathrm{Sr} /{ }^{86} \mathrm{Sr}$ seawater signature rise during the Triassic times in Provençal Domain (cf. [26]), as well as the involved Triaasic carbonates by meteoric waters. 


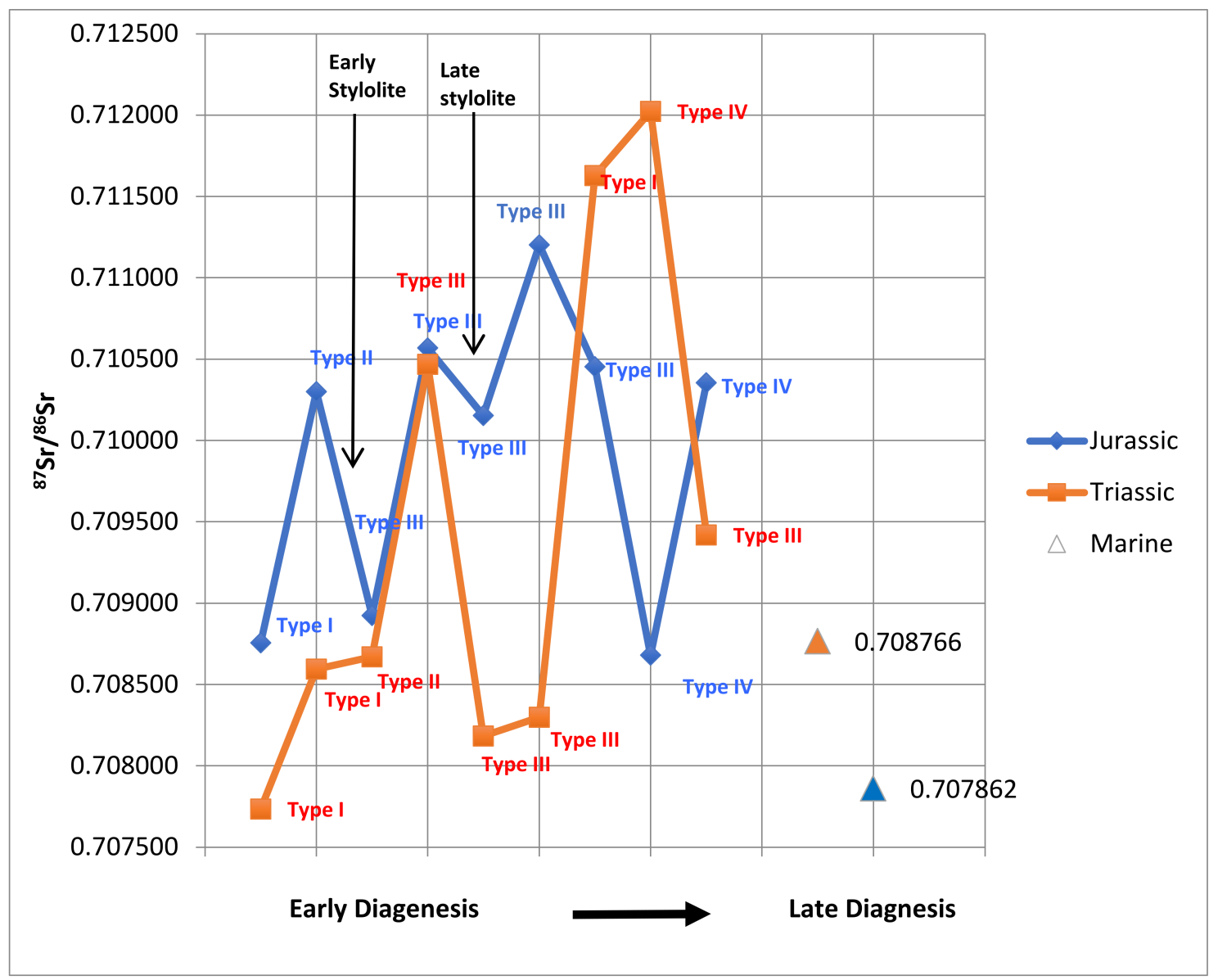

Figure 15. The rate of change of ${ }^{87} \mathrm{Sr} /{ }^{86} \mathrm{Sr}$ according to time in order to illustrate the number of jumps between the different diagenetic conditions in both sections separately. The number of jumps (down and up) can calculate the number of fault reactivation $(n=20)$.

The repeated injection of hydrothermal fluids into the Mesozoic succession in the Provençal Domain and formation of many phases of saddle dolomites might have been expelled by from overpressured lithologies and fluxed through deep-seated faults (Figures 4, 6, 10 and 14; e.g., [30]). The high Sr isotopic ratios of saddle dolomite suggest that the hydrothermal fluids interacted with the crystalline basement and/or siliciclastic deposits [12,30].

The radiogenic enrichment of the Jurassic samples could be deviated from open ocean evaporite, however, the dolomitizing fluids are not in agreement with the involvement of the evaporites which are missing here. If a high strontium ratio represents the involvement of evaporites, then it is expected that a high strontium ratio would correlate with the depletion of oxygen values. Mostly, the dolomitizing fluids that have high strontium ratios would have been enriched with heavier oxygen isotope values, confirming the involvement of evaporites (e.g., [48]). However, this scenario is not in agreement with our Jurassic dolomite samples and the regional geology, therefore the interaction of hot dolomitizing fluid mostly interacted with the Argentera crystalline basement before flowing up to the Jurassic carbonate rocks.

In contrast to Jurassic dolomites, some Triassic dolomites have significantly lower ${ }^{87} \mathrm{Sr} /{ }^{86} \mathrm{Sr}$ values with respect to the open marine facies values. The depletion of ${ }^{87} \mathrm{Sr} /{ }^{86} \mathrm{Sr}$ ratios started from the Late Triassic up to the Turonian recording pulses of mid-oceanic hydrothermal fluxes that related to the opening and closure of the North Atlantic Ocean [27]. There were several short-term excursions of radiogenic depletion of ${ }^{87} \mathrm{Sr} /{ }^{86} \mathrm{Sr}$ ratios highlighting these pulses. The authors of [49] reported excursions of very low ${ }^{87} \mathrm{Sr} /{ }^{86} \mathrm{Sr}$ ratios during three short periods (Early Jurassic, Early Cretaceous and Late Cretaceous) that are linked to the rate of hydrothermal activity as a consequence of increased 
ocean-crust production at the mid-oceanic ridges. Therefore, some of our data in the Triassic could be partly influenced by the short-term excursions of strontium depletion after the deposition of Triassic sediments. In addition, following McArthur's Graph, our data display that Type II saddle dolomites are associated with a jump-down of the ${ }^{87} \mathrm{Sr} /{ }^{86} \mathrm{Sr}$ isotope values. The repetition of the jump-down and jump-up graph of each type of dolomite follows the same trends in the Triassic and Jurassic samples (Figure 15). The graph suggests that the Triassic and Jurassic sections had the same stratigraphic position (not separated) prior to the precipitation of the calcite phase (Type IV).

The ultimate diagenetic phase (Type IV) records the highest enrichment radiogenic composition (0.712023) from the Triassic and the lowest ${ }^{87} \mathrm{Sr} /{ }^{86} \mathrm{Sr}$ ratio $(0.708680)$ from the Jurassic samples. This phase attributed to the late stage of calcite cementation and was consistent with the very depleted $\delta^{18} \mathrm{O}_{\mathrm{VPDB}}$ values and the lowest $\delta^{13} \mathrm{C}_{\mathrm{VPDB}}$ values (cf. [50]). The meteoric water has the lowest $\delta^{18} \mathrm{O}_{\mathrm{VPDB}}$ values and highest ${ }^{7} \mathrm{Sr} /{ }^{86} \mathrm{Sr}$ ratios $(0.709630$ to 0.70948 , [51]). The increasing recharge from meteoric water could apply to the late stage of Fe-poor calcite precipitation and is probably related to an uplift of the buried Triassic-Jurassic rocks (Figures 11-14). The late calcite cement $C 1_{\mathrm{J}}$ in the Jurassic section shifted toward decreasing Sr isotope values, and appears to be more affected by other sources besides meteoric water (in contrast to Triassic calcite value). On the basis of the tectonic graph, $\mathrm{C}_{\mathrm{T}}$ and $\mathrm{C} 1_{\mathrm{J}}$ are attributed to two different fluids, which were stratigraphically separated during the uplifting of these units (outcrops). Consequently, the lowering of $\mathrm{Sr}$ isotope compositions $\left(\mathrm{Cl}_{\mathrm{J}}\right)$ in this study, especially in the Jurassic section, could be partly linked to the pulses of the seafloor hydrothermal activity that lowered the ${ }^{87} \mathrm{Sr} /{ }^{86} \mathrm{Sr}$ ratios. During the late calcite event, the former dolomitized rocks were strongly brecciated with an in situ accumulation of crushed fragments. This event reveals that an intense tectonic activity was ongoing during the late fluid migration $[30,52,53]$, which could be associated to Late Cretaceous-Eocene times, where general strike-slip fault systems occurred in the European paleomargin [52,53].

The Triassic-Jurassic carbonate seawater in Provençal Domain could partly have been influenced by the input of various rates of weathering and erosion of young volcanic rocks and/or old granitic rocks. These inputs probably persisted after the deposition of Mesozoic succession in Provencal Domain. Finally, fluctuations in the rising and falling of ${ }^{87} \mathrm{Sr} /{ }^{86} \mathrm{Sr}$ seawater signatures have already been reported [26,27], therefore, the values of the ${ }^{87} \mathrm{Sr} /{ }^{86} \mathrm{Sr}$ fluctuations are the important factors and may have influence the diagenesis products beside the hydrothermal fluids and meteoric waters in Provencal Domain (Figure 15).

\section{Conclusions}

The main conclusions derived from this integrated field, petrographic and geochemical study of dolomitization in the Mesozoic carbonate succession, Provençal Domain, Maritime Alps, SE France show that:

1. The succession is extensively dolomitized with abundant breccia and zebra textures, and complex fracturing paths due to the influence of repeatedly injections of hydrothermal fluids.

2. Three diagenetic settings are recognized:

(i) An eogenetic realm with weak diagenetic imprints. This setting is confirmed by $\delta^{18} \mathrm{O}_{\mathrm{VPDB}}$ and $\delta^{13} \mathrm{CVPDB}_{\mathrm{V}}$ values that fit the inverse "J" Lohmann curve and meteoric line models.

(ii) A second mesogenetic setting in two phases, the first one started with the generation of wispy stylolites ("early dolomite"), and various networks of fractures as well as zebra and breccia fabrics. The fabrics are associated with a first generation of medium- to coarse-grained dominantly euhedral saddle dolomites (Type II) formed through the migration of hot dolomitizing fluids. This occured during early Cretaceous times and was related to the extensional and transtensional tectonics of the European paleomargin of the Alpine Tethys. In the second phase (our Type III dolomite), further physical brecciation and cataclastic fractures cross cut the Type II dolomite under deeper burial conditions 
with late stylolite-related fractures (tension gashes). The $\delta^{18} \mathrm{O}_{\mathrm{VPDB}}$ values become more depleted with subsequent increases in the saddle crystal sizes. The $\delta^{18} \mathrm{O}_{\mathrm{VPDB}}$ saddle dolomite values (up to $-8.3 \%$ in Type II and up to $-11.6 \%$ in Type III) suggest that at least two pulses of hydrothermal fluids during the precipitation of saddle dolomites occurred. The chemical composition of the successive saddle dolomites was progressively modified from nonferroan to ferroan-rich in an open system and the positive co-variant trends of ${ }^{87} \mathrm{Sr} /{ }^{86} \mathrm{Sr}$ vs. $\delta^{18} \mathrm{O}_{\mathrm{VPDB}}$ strongly support an origin from from hot fluids in a deep burial-reducing mesogenetic environment.

(iii) The ultimate diagenesis is related to the late phase of calcite cement precipitation, synchronous with $\mathrm{Fe}$ and $\mathrm{Mn}$ depletion and extra-negative $\delta^{18} \mathrm{O}_{\mathrm{VPDB}}-\delta^{13} \mathrm{C}_{\mathrm{VPDB}}$ values. A meteoric water under near-surface conditions during telogenesis and uplifting of the Triassic-Jurassic succession is inferred.

3. The depletion and enrichment of radiogenic strontium signals could also be linked to the pulses of mid-oceanic hydrothermal fluxes and an input of riverine fluxes during the opening and closure of the North Atlantic Ocean, beside the involvement of hydrothermal fluids and meteoric waters on Triassic-Jurassic successions.

Author Contributions: Conceptualization, N.S.; methodology, N.S.; software, N.S.; validation, N.S. and A.P.; formal analysis, N.S. and A.P.; investigation, N.S. and A.P.; resources, N.S.; data curation, N.S.; writing-original draft preparation, N.S.; writing-review and editing, H.M. and A.P.; visualization, N.S.; supervision, A.P. and H.M.; project administration, N.S., A.P. and H.M. All authors have read and agreed to the published version of the manuscript.

Funding: This research received no external funding.

Acknowledgments: The authors kindly thank Luca Martire, Luca Barale, and Carlo Bertok from Dipartimento di Scienze della Terra, Università di Torino, Italy for collecting samples at the field "Provençal Domain". We acknowledge also the support of Philippe Muchez from Department of Earth and Environmental Sciences, KUL-university-Belgium for helpful revision of the manuscript.

Conflicts of Interest: The authors declare no conflict of interest.

\section{References}

1. Machel, H.G. Concepts and models of dolomitization: A critical reappraisal. In The Geometry and Petrogenesis of Dolomite Hydrocarbon Reservoirs; Braithwaite, C.J.R., Rizzi, G., Darke, G., Eds.; Geological Society of London: London, UK, 2004; Volume 235, pp. 7-63.

2. Fu, Q.; Quing, H. Medium and coarsely crystalline dolomites in the Middle Devonian Ratner Formation, southern Saskatchewan, Canada: Origin and pore evolution. Carbonates Evaporites 2011, 26, 111-125. [CrossRef]

3. Land, S. The origin of massive dolomite. J. Geol. Educ. 1985, 33, 87-110. [CrossRef]

4. Machel, G.; Mountjoy, W. Chemistry and environment of dolomitization: A reappraisal. Earth Sci. Rev. 1986, 23, 175-222. [CrossRef]

5. Hardie, A. Dolomitization: A critical view of some current views. J. Sediment. Petrol. 1987, 57, $166-183$. [CrossRef]

6. Qing, H.; Mounjoy, W. Formation of coarsely crystalline, hydrothermal dolomite reservoir in the Presqu'ile Barrier, western Canada Sedimentary Basin. Am. Assoc. Pet. Geol. 1994, 78, 55-77.

7. Al-Aasm, I.S. Origin and characterization of hydrothermal dolomite in the Western Canada Sedimentary Basin. J. Geochem. Explor. 2003, 78-79, 9-15. [CrossRef]

8. Smith, B. Origin and reservoir characteristics of Upper Ordovician Trenton-Black River hydrothermal dolomite reservoirs in New York. Bull. Am. Assoc. Pet. Geol. 2006, 90, 1691-1718. [CrossRef]

9. Lavoie, D.; Chi, G. Lower Paleozoic foreland basins in eastern Canada: Tectono-thermal events recorded by faults, fluids and hydrothermal dolomites. Bull. Can. Pet. Geol. 2010, 58, 17-35. [CrossRef]

10. Hardie, A. On the significance of evaporites. Annu. Rev. Earth Planet. Sci. 1991, 19, 131-168. [CrossRef] 
11. Iannace, A.; Gasparrini, M.; Gabellone, T.; Mazzoli, S. Late dolomitization in basinal limestones of the southern Apennines fold and thrust belt (Italy). Oil Gas Sci. Technol. Rev. d'IFP Energ. Nouv. 2012, 67, 59-75. [CrossRef]

12. Davies, G.; Smith, L. Structurally controlled hydrothermal dolomite reservoir facies: An overview. Am. Assoc. Pet. Geol. Bull. 2006, 90, 1641-1690. [CrossRef]

13. Mohn, G.; Manatschal, G.; Muntener, O.; Beltrando, M.; Masini, E. Unravelling the interaction between tectonic and sedimentary processes during lithospheric thinning in the Alpine Tethys margins. Int. J. Earth Sci. 2010, 99, 75-101. [CrossRef]

14. Barale, L.; Bertok, C.; Talabani, S.N.; d'Atri, A.; Martire, L.; Piana, F.; Préat, A. Very hot, very shallow hydrothermal dolomitization: An example from the Maritime Alps (north-west Italy-south-east France). Sedimentology 2016, 63, 2037-2065. [CrossRef]

15. Durand, M. Permian to Triassic continental successions in southern Provence (France): An overview. Geol. Soc. Italy 2008, 127, 697-716.

16. De Graciansky, C.; Lemoine, M. Early Cretaceous extensional tectonics in the southwestern French Alps: A consequence of North-Atlantic rifting during Tethyan spreading. Bull. Société Géologique Fr. 1988, 8, 733-737. [CrossRef]

17. Dardeau, G.; Pascal, A. La régression fin-Jurassique dans les Alpes-Maritimes: Stratigraphie, faciès, environnements sédimentaires et influence du bâti structural dans l'arc de Nice. Bull. Bur. Rech. Géologiques Minières 1982, 3, 193-204.

18. Debrand-Passard, S.; Courbouleix, S.; Lienhart, J. Geological synthesis of south-east France. Bur. Geol. Min. Res. Orléans 1984, 125, 615.

19. McArthur, M.; Howarth, J.; Shields, A. Strontium isotope stratigraphy. In The Geologic Time Scale 2012; Gradstein, F.M., Ogg, J.G., Schmitz, M., Ogg, G.M., Eds.; Elsevier: Boston, MA, USA, 2012; Volume 2, pp. 127-144.

20. Nelson, A. Significance of fracture sets associated with stylolite zones. Am. Assoc. Pet. Geol. Bull. 1981, 65, 2417-2425.

21. Eren, M. Origin of stylolite related fractures in Atoka Bank Carbonates, Eddy County, New Mexico, U.S.A. Carbonates Evaporites 2005, 20, 42-49. [CrossRef]

22. Jones, E.; Tarney, J.; Baker, H.; Gerouki, F. Tertiary granitoids of Rhodope, Northern Greece: Magmatism related to extensional collapse of the Hellenic orogen? Tectonophysics 1992, 210, 295-314. [CrossRef]

23. Veizer, J.; Hoefs, J. The nature of $\mathrm{O}^{18} / \mathrm{O}^{16}$ and $\mathrm{C}^{13} / \mathrm{C}^{12}$ secular trends in sedimentary carbonate rocks. Geochim. Cosmochim. Acta 1976, 40, 1387-1395. [CrossRef]

24. Veizer, J.; Ala, D.; Azmy, K.; Bruckschen, P.; Buhl, D.; Bruhn, F.; Carden, G.A.F.; Diener, A.; Ebneth, S.; Goddéris, Y.; et al. ${ }^{87} \mathrm{Sr} /{ }^{86} \mathrm{Sr}, \delta^{13} \mathrm{C}$ and $\delta^{18} \mathrm{O}$ evolution of Phanerozoic seawater. Chem. Geol. 1999, 161, 59-88. [CrossRef]

25. Katz, M.E.; Wright, J.D.; Miller, K.G.; Cramer, B.S.; Fennel, K.; Falkowski, P.G. Biological overprint of the geological carbon cycle. Mar. Geol. 2005, 217, 323-338. [CrossRef]

26. Korte, C.; Kozur, W.; Bruckschen, P.; Veizer, J. Strontium isotope evolution of Late Permian and Triassic seawater. Geochim. Cosmochim. Acta 2003, 67, 47-62. [CrossRef]

27. Jones, E.; Jenkyns, C.; Coe, L.; Hesselbo, P. Strontium isotopic variations in Jurassic and Cretaceous seawater. Geochim. Cosmochim. Acta 1994, 58, 3061-3074. [CrossRef]

28. Gregg, J.M.; Sibley, D.F. Epigenetic dolomitization and origin of xenotopic dolomite texture. J. Sediment. Res. 1984, 54, 908-931.

29. Sibley, F.; Gregg, M. Classification of dolomite rock textures. J. Sediment. Res. 1987, 57, 967-975.

30. Salih, N.; Mansurbeg, H.; Kolo, K.; Gerdes, A.; Préat, A. In situ U-Pb dating of hydrothermal diagenesis in tectonically controlled fracturing in the Upper Cretaceous Bekhme Formation, Kurdistan Region-Iraq. Int. Geol. Rev. 2019, 0020-6814, 1938-2839. [CrossRef]

31. Kretz, R. Carousel model for the crystallization of saddle dolomite. J. Sediment. Petrol. 1992, 62, 551-574.

32. Nelson, A. Natural fracture systems: Description and classification. Am. Assoc. Pet. Geol. Bull. 1979, 63, 2214-2232.

33. Morad, S.; Al Suwaidi, M.; Mansurbeg, H.; Morad, D.; Ceriani, A.; Papagoni, M.; Al-Aasm, I. Diagenesis of a limestone reservoir (Lower Cretaceous), Abu Dhabi, United Arab Emirates: Comparison between the anticline crest and flanks. Sediment. Geol. 2019, 380, 127-142. [CrossRef] 
34. Carraro, F.; Dal Piaz, V.; Franceschetti, B.; Malaroda, R.; Sturani, C.; Zanella, E. Note Illustrative della Carta Geologica del Massiccio dell'Argentera alla scala 1: 50.000. Mem. Soc. Geol. Italy 1970, 9, 557-663.

35. Malaroda, R. L'Argentera meridionale-Memoria illustrativa della "Geological Map of Southern Argentera Massif (Maritime Alps) 1:25,000". Sci. Géologiques-Mémoires 1999, 51-52, 241-331.

36. Bigot-Cormier, F.; Poupeau, G.; Sosson, M. Dénudations différentielles du massif cristallin externe alpin de l'Argentera (Sud-Est de la France) révélées par thermochronologie traces de fission (apatites, zircons). Comptes Rendus l'Académie Sci. Paris 2000, 330, 363-370. [CrossRef]

37. Wierzbicki, R.; Dravis, J.; Al-Aasm, I.; Harland, N. Burial dolomitization and dissolution of Upper Jurassic Abenaki platform carbonates, Deep Panuke reservoir, Nova Scotia, Canada. Am. Assoc. Pet. Geol. 2006, 90, 1843-1861. [CrossRef]

38. Crampton, L.; Allen, A. Recognition of forebulge unconformities associated with early-stage Foreland Basin development-Example from the North Alpine Foreland Basin. Am. Assoc. Pet. Geol. Bull. 1995, 79, 1495-1514.

39. D'Arti, A.; Piana, F.; Barale, L.; Bertok, C.; Martire, L. Geological setting of the southern termination of Western Alps. Int. J. Earth Sci. 2016, 105, 1831-1858.

40. Lohmann, C. Geochemical patterns of meteoric diagenetic systems and their application to studies of paleokarst. In Paleokarst; James, N.P., Choquette, P.W., Eds.; Springer: New York, NY, USA, 1988; pp. 58-80.

41. Allan, R.; Mathhews, K. Carbon and oxygen isotopes as diagenetic and stratigraphic tools: Data from surface and subsurface Barbados, West Indies. Geology 1977, 5, 16-20. [CrossRef]

42. Nader, H.; Swennen, R.; Ottenburgs, R. Karst-meteoric dedolomitisation in Jurassic carbonates, Lebanon. Geol. Belg. 2003, 6, 3-23.

43. Moore, H. Carbonate Diagenesis and Porosity. Dev. Sedimentol. 1989, 46, 338.

44. Wright, P.; Harris, P. Carbonate Dissolution and Porosity Development in the Burial (mesogenetic) Environment. In Proceedings of the Oral presentation at American Association of Petroleum Geologists, Annual Convention and Exhibition, Pittsburgh, PA, USA, 19-22 May 2013.

45. Salih, N.; Kamal, M.; Préat, A. Classical observations and stable isotopes for identification the diagenesis of Jeribe formation at Jambour oil Fields-Kurdistan Region-Iraq. Pet. Sci. Technol. 2019, 37, 1548-1556. [CrossRef]

46. Shah, M.; Nader, H.; Garcia, D.; Swennen, E.R. Hydrothermal dolomites in the Early Albian (Cretaceous) platform carbonates (NW Spain): Nature and origin of dolomites and dolomitizing fluids. Oil Gas Sci. Technol. 2012, 67, 97-122. [CrossRef]

47. Faure, G.; Assereto, R.; Tremba, L. Strontium isotope composition of marine carbonates of Middle Triassic to Early Jur assic age, Lombardic Alps, Italy. Sedimentology 1978, 25, 523-543. [CrossRef]

48. Li, S.; Levin, E.; Chesson, A. Continental scale variation in ${ }^{17} \mathrm{O}$-excess of meteoric waters in the United States. Geochim. Cosmochim. Acta 2015, 164, 110-126. [CrossRef]

49. Jones, E.; Jenkyns, C. Seawater strontium isotopes, oceanic anoxic events, and seafloor hydrothermal activity in the Jurassic and Cretaceous. Am. J. Sci. 2001, 301, 112-149. [CrossRef]

50. Salih, N.; Mansurbeg, H.; Kolo, K.; Préat, A. Hydrothermal Carbonate Mineralization, Calcretization, and Microbial Diagenesis Associated with Multiple Sedimentary Phases in the Upper Cretaceous Bekhme Formation, Kurdistan Region-Iraq. Geosciences 2019, 9, 459. [CrossRef]

51. Dong, S.; Chen, D.; Qing, H.; Zhou, X.; Wang, D.; Guo, Z.; Jiang, M.; Qian, Y. Hydrothermal alteration of dolostones in the Lower Ordovician, Tarim Basin, NW China: Multiple constraints from petrology, isotope geochemistry and fluid inclusion microthermometry. Mar. Pet. Geol. 2013, 46, 270-286. [CrossRef]

52. Sanchez, G.; Rolland, Y.; Jolivet, M.; Brichau, S.; Corsini, M.; Carter, A. Exhumation controlled by transcurrent tectonics: The Argentera-Mercantour massif (SW Alps): Exhumation controlled by transcurrent tectonics in SW Alps. Terra Nova 2011, 23, 116-126. [CrossRef]

53. Dumont, T.; Schwartz, S.; Guillot, S.; Simon-Labric, T.; Tricart, P.; Jourdan, S. Structural and sedimentary records of the Oligocene revolution in the Western Alpine arc. J. Geodyn. 2012, 56-57, 18-38. [CrossRef] 